Rubbery Wound Closure Adhesives. I. Design, Synthesis, Characterization, and Testing of Polyisobutylene-Based Cyanoacrylate Homo- and Co-networks

\begin{tabular}{|r|l|}
\hline Journal: & Journal of Polymer Science, Part A \\
\hline Manuscript ID: & JPOL-A-14-0833 \\
\hline Wiley - Manuscript type: & Original Article \\
\hline Keywords: & $\begin{array}{l}\text { networks }<\mathrm{N}, \text { rubber }<\mathrm{R}, \text { adhesives }<\text { A, polyisobutylene, wound } \\
\text { dressing, cyanoacrylate }\end{array}$ \\
\hline \multicolumn{2}{|l}{} \\
\hline
\end{tabular}

SCHOLARONE ${ }^{\text {m }}$

Manuscripts 


\title{
Rubbery Wound Closure Adhesives. I. Design, Synthesis, Characterization, and Testing of Polyisobutylene-Based Cyanoacrylate Homo- and Co-networks
}

\author{
Istvan Szanka ${ }^{1,2}$, Amalia Szanka $^{1,2}$, Sinan Şen ${ }^{3}$, Nihan Nugay $^{4}$ and Joseph P. Kennedy ${ }^{1}$ \\ ${ }^{1}$ Institute of Polymer Science, The University of Akron, Akron, OH 44325-3909, USA \\ ${ }^{2}$ Polymer Chemistry Group, Institute of Materials and Environmental Chemistry, Research Centre for \\ Natural Sciences, Hungarian Academy of Sciences, H-1117 Budapest, Magyar tudósok krt. 2, Hungary \\ ${ }^{3}$ Department of Polymer Engineering, Yalova University, Yalova, 77100, Turkey \\ ${ }^{4}$ Department of the Chemistry, Polymer Research Center, Boğaziçi University, İstanbul, 34342, Turkey \\ Correspondence to: Joseph P. Kennedy (E-mail: josep19@uakron.edu)
}

\begin{abstract}
Novel rubbery wound closures containing various proportions and molecular weights of polyisobutylene (PIB) and poly(2-octyl cyanoacrylate) $[\mathrm{P}(\mathrm{OctCA})]$ for potential clinical use were designed, synthesized, characterized, and tested. Homo-networks were prepared by crosslinking 3arm star-shaped PIBs fitted with terminal cyanoacrylate groups, $\left[\varnothing(\mathrm{PIB}-\mathrm{CA})_{3}\right]$, and co-networks by copolymerizing $\varnothing(\mathrm{PIB}-\mathrm{CA})_{3}$ with OctCA using N-dimethyl-p-toluidine (DMT). Neat $\varnothing(\mathrm{PIB}-\mathrm{CA})_{3}$, and $\varnothing(\mathrm{PIB}-\mathrm{CA})_{3} /$ OctCA blends, upon contact with initiator, polymerize within seconds to optically transparent strong rubbery co-networks, $\varnothing(\mathrm{PIB}-\mathrm{CA})_{3}$-Co-P(OctCA). Homo- and co-network formation was demonstrated by sol/gel studies, and structures and properties were characterized by a battery of techniques. The $\mathrm{T}_{\mathrm{g}}$ of $\mathrm{P}(\mathrm{OctCA})$ is $58{ }^{\circ} \mathrm{C}$ by DSC, and $75{ }^{\circ} \mathrm{C}$ by DMTA. Co-networks comprising $25 \%$ $\varnothing(\mathrm{PIB}-\mathrm{CA})_{3}\left(\mathrm{M}_{\mathrm{n}}=2400 \mathrm{~g} / \mathrm{mol}\right)$ and $75 \% \mathrm{P}(\mathrm{OctCA})$ are stronger and more extensible than skin. Short and long term creep studies show co-networks exhibit high dimensional stability and $<6 \%$ creep strain at high loading. Co-networks upon contact with DMT polymerize within seconds and produce transparent rubbery coatings on porcine skin. When deposited on porcine skin co-networks yield hermetically-adhering clear rubbery coatings. Strips of porcine skin coated with co-networks could be stretched and twisted without compromising membrane integrity. The co-network is non-toxic to L929 mouse fibroblasts.
\end{abstract}

KEYWORDS: ((please insert at least five keywords))

\section{INTRODUCTION}

Polyisobutylene (PIB), one of the best, arguably the best, synthetic rubbery biomaterials, is superbly bio- and hemocompatible, chemically resistant, and sterilizable. ${ }^{1-3}$ Further, the PIB molecule can be readily shaped (linear, starshaped, branched, etc.), its molecular weight can be easily controlled from the dimer to many thousands of monomer units, and it can be fitted with a great variety of functional groups. ${ }^{4,5}$ And, as the cost of the monomer is rather low ( $\$ 0.80 / \mathrm{lb}$. as of this writing), the cost of the bundle of properties represented by $\mathrm{PIB}$ is relatively low.

Some time ago we theorized that homonetworks of 3-arm star-shaped PIBs fitted with terminal cyanoacrylate (CA) groups [ $\varnothing(\mathrm{PIB}-$ $\left.\mathrm{CA})_{3}\right]$, and co-network of $\varnothing(\mathrm{PIB}-\mathrm{CA})_{3}$ plus 2-octyl cyanoacrylate (OctCA) could be starting materials for clinically useful flexible topical occlusive wound closure adhesives. Figure 1 shows the structures of these starting materials. 


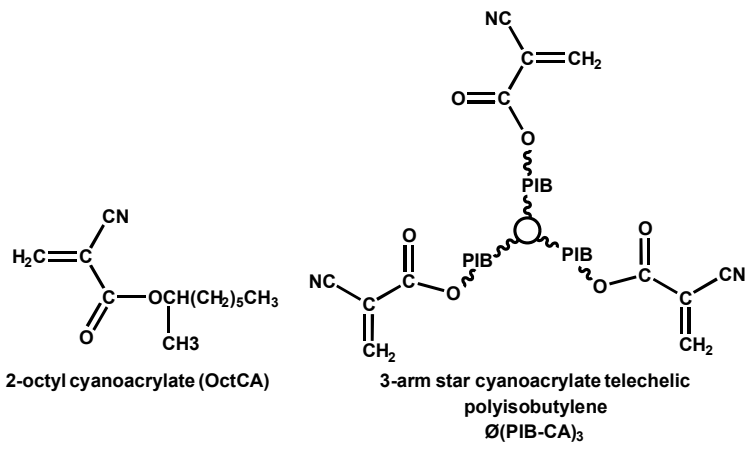

FIGURE 1 Structures of Starting Materials of PIB-based Homo- and Co-networks

Commercially available ethyl (Et)-, butyl (Bu)-, 2-octyl (Oct)-cyanoacrylates are well-known starting materials for wound closure adhesives, however, they exhibit (a) undesirably low viscosity ("runniness"), (b) undesirable stiffness of the coatings they produce, and (c) toxicity, particularly of the lower CAs. ${ }^{6,7}$ We hypothesized that wound closures made with appropriately high molecular weight $\varnothing(\text { PIB-CA })_{3}$ would be: (a) more flexible than closures made with even the best contemporary alkyl-CAbased products, (b) much easier to handle because of their higher viscosity than current "runny" alkyl-CAs, and (c) less toxic than the lower alkyl-CAs due to their higher molecular weight. In view of PIB's outstanding biocompatibility and excellent gas and liquid barrier properties, we expected that the envisioned PIB-based networks and co-network will provide the moist environment essential for wound healing and lead to occlusive wound dressings impermeable to microorganisms. Further, such networks/co-networks would not lead to scab formation, so epidermal cells would be able to move rapidly over the surface of the dermis through the gelatinous exudate that collects at the wound surface. Also, these highly hydrophobic materials would not adhere to the wound so that on removal no damage is done to granulating tissue.
This paper concerns homopolymerization of $\varnothing(\mathrm{PIB}-\mathrm{CA})_{3}$ to homo-networks, and copolymerization of $\varnothing$ (PIB-CA $)_{3}$ with OctCA to co-networks by the use of DMT initiator, together with the characterization of these products. We also studied the homopolymerization of OctCA and various molecular weight $\varnothing(\mathrm{PIB}-\mathrm{CA})_{3} \mathrm{~S}$, and the copolymerization of these $\varnothing(\mathrm{PIB}-\mathrm{CA})_{3} \mathrm{~S}$ with various proportions of OctCA, characterized the structures, and studied properties of the resulting homo- and copolymers (i.e., homoand co-network, respectively). Extraction studies indicated the formation of networks. Both homo- and copolymerizations occur very rapidly (seconds to minutes) and set times (i.e., the time coatings become essentially tack free) can be controlled by the use of appropriate amounts of initiator. The molecular weight of the $\varnothing(\mathrm{PIB}-\mathrm{CA})_{3}$ can be adjusted to yield viscous liquids for easy deposition on uneven or vertical surfaces. Select co-networks produce optically clear strong rubbery biocompatible films hermetically adhering to the surface of ventral porcine skin rendering them suitable for occlusive skin closure adhesives.

\section{EXPERIMENTAL}

\section{Materials}

Trimethyl-1,3,5-benzenetricarboxylate (95\%), allyltrimethylsilane (ATMS, 98\%), anthracene (99\%), N-dimethyl-p-toluidine (DMT, 99\%), $\mathrm{N}, \mathrm{N}, \mathrm{N}^{\prime}, \mathrm{N}^{\prime}$-tetramethylethylene diamine (TMEDA, 99.5\%), maleic anhydride (MA, 99\%) and $\mathrm{TiCl}_{4}$ were purchased from Aldrich, and used as received. 2-octyl cyanoacrylate (OctCA) from Chenso contained $30 \mathrm{ppm}$ of $\mathrm{SO}_{2}$ and 1000 ppm BHA stabilizer, and was used without further purification. NMR spectroscopy indicated that this product also contained $\sim 2 \%$ 1-octyl cyanoacrylate. Isobutylene 99.9\% (ExxonMobil), methylmagnesium bromide (Acros Organics), 9-borabicyclo[3.3.1]nonane solution (Acros Organics), sulfur dioxide (Praxair), potassium hydroxide (Fisher Scientific), hydrogen peroxide 30\% (EDM Chemicals), methanol (Fisher Scientific) and abs. 
ethanol (Decon Labs.) were used as received. Benzene (Aldrich), tetrahydrofuran (Aldrich) and p-xylene (Alfa Aesar) were dried and distilled over sodium and benzophenon. Hexanes (Aldrich) and methylene chloride (Aldrich) were distilled over $\mathrm{CaH} 2$ prior to use. Ventral porcine skin ( $20 \times 30 \mathrm{~cm}$ sheets) was purchased from a local butcher. The surface of the skin was cleaned by rubbing with a swab of cotton saturated with $70 \%$ aqueous isopropanol.

\section{Instruments and Instrumental Procedures}

Proton $\left({ }^{1} \mathrm{H}\right)$ NMR spectroscopy, (Varian Gemini 300 and $500 \mathrm{MHz}$ instruments and deuterated chloroform as solvent) was used to determine chemical structures, chain-end functionalities and molecular weights $\left(M_{n}\right)$.

Gel permeation chromatography (GPC) eluograms were obtained with a Waters GPC instrument equipped with a series of three Waters Styragel-HR columns (HR-1, HR-4E, HR$5 E$ ), a refractive index detector (Waters 2414) and a multiangle laser light scattering detector (Dawn EOS, Wyatt Technology). Samples were dissolved in THF, the flow rate was $1 \mathrm{~mL}$ $\mathrm{THF} / \mathrm{min}$, and column temperature was $35^{\circ} \mathrm{C}$.

Differential scanning calorimetry was performed with a DSC Q2000 TA instrument working under a nitrogen atmosphere. Approximately $8 \mathrm{mg}$ samples were placed in aluminum pans, sealed by a quick press, and heated at a scanning rate of $10^{\circ} \mathrm{C} / \mathrm{min}$.

Dynamic mechanical properties of conetwork films were determined with a dynamic mechanical analyzer (DMA-Q800, TA Instruments) in film tension mode at $1 \mathrm{~Hz}$, at $3^{\circ} \mathrm{C} / \mathrm{min}$ heating rate in the -100 to $250^{\circ} \mathrm{C}$ temperature range. The average dimensions of the films were $0.2 \times 10 \times 30 \mathrm{~mm}^{3}$. Permanent deformation was determined by isothermal creep tests on select co-networks using constant stresses of $0.05 \mathrm{MPa}$ and $0.5 \mathrm{MPa}$ at $30{ }^{\circ} \mathrm{C}$ for $15 \mathrm{~min}$, and recovery followed by load removal for $25 \mathrm{~min}$.

Creep TTS tests were carried out using 0.5 MPa creep stress at different temperatures. Stress was applied for $15 \mathrm{~min}$ at each temperature in the -40 to $40{ }^{\circ} \mathrm{C}$ range, in $20{ }^{\circ} \mathrm{C}$ steps. Timedependent deformation was measured in terms of percent strain. The master curve indicating long-time creep behavior was generated by Thermal Advantage TTS software of the DMA instrument.

Stress strain properties of $65 \mathrm{~mm}$ long microdumbell-shaped samples were determined by following ASTM D638-02a with Texture Analyzer TA.XTplus tester, 5 kilo load cell at $5 \mathrm{~mm} / \mathrm{min}$ crosshead speed. Samples (0.2-0.25 $\mathrm{mm}$ thick) were punched from solution (THF) cast films.

Extraction (sol/gel) studies were carried out with cast films of homo- and co-networks, dried in vacuum for $24 \mathrm{~h}$ at $60^{\circ} \mathrm{C}$, weighed, placed in $50 \mathrm{~mL}$ freshly distilled THF, and gently stirred for $24 \mathrm{~h}$ at room temperature. Then, the samples were removed from the THF, dried in vacuum for $24 \mathrm{~h}$ at $60{ }^{\circ} \mathrm{C}$, and weighed. The wt\% of sol fractions (extractables, $E$ ) was calculated by:

$$
E(\%)=\frac{\left(m_{d r y}-m_{e x}\right)}{m_{d r y}} 100
$$

where $m_{\text {dry }}$ and $m_{e x}$ are masses of samples before and after extraction. Averages of three determinations are reported.

Cytotoxicity was tested following the guidelines of ISO 10993-5, at NAMSA ${ }^{\text {TM }}$ test facility (Lab. Number 14T-48248). The L-929 mouse fibroblast cells were propagated and maintained in flasks containing $92 \% \mathrm{Gibco}^{\circledR}$ Minimum Essential Medium (MEM) with Earle's salts, $5 \%$ fetal bovin serum, $2 \%$ antibiotics (100 units $/ \mathrm{mL}$ penicillin, $100 \mathrm{\mu g} / \mathrm{mL}$ streptomycin and $2.5 \mu \mathrm{g} / \mathrm{mL}$ amphotericin B), and $1 \%(2 \mathrm{mM})$ L-glutamine (1X MEM) at $37{ }^{\circ} \mathrm{C}$ with $5 \%$ carbon dioxide $\left(\mathrm{CO}_{2}\right)$. Cells were seeded in $10 \mathrm{~cm}^{2}$ cell culture wells and incubated at $37{ }^{\circ} \mathrm{C}\left(5 \% \mathrm{CO}_{2}\right)$ to obtain subconfluent monolayers of cells prior to use. The co-network and controls (HDPE and Latex Gloves) were extracted in $1 \mathrm{X}$ MEM solution (extraction ratio: $6 \mathrm{~cm}^{2}: 1 \mathrm{~mL}$ ) at $37^{\circ} \mathrm{C}$ for 24 hours. The growth medium contained (in triplicate) $10 \mathrm{~cm}^{2}$ wells, replaced with $2.0 \mathrm{~mL}$ of co-network, reagent control, negative control (HDPE) and positive control (Latex Gloves) 
extracts, respectively. The wells were incubated at $37{ }^{\circ} \mathrm{C}$ in $5 \% \quad \mathrm{CO}_{2}$ for 48 hours. After incubation, the cells were examined by microscopy (100X) to evaluate cellular characteristic and percent lysis.

\section{Syntheses and Chemical Manipulations}

\section{Synthesis and Characterization of Anthracene- Protected 2-Cyano Acrylic Acid}

The synthesis of this material was carried out by the method described by Kwon and Kennedy. ${ }^{8}$ Figure 2 shows the NMR spectrum of anthracene-protected 2-cyano acrylic acid and its precursor, together with assignments.

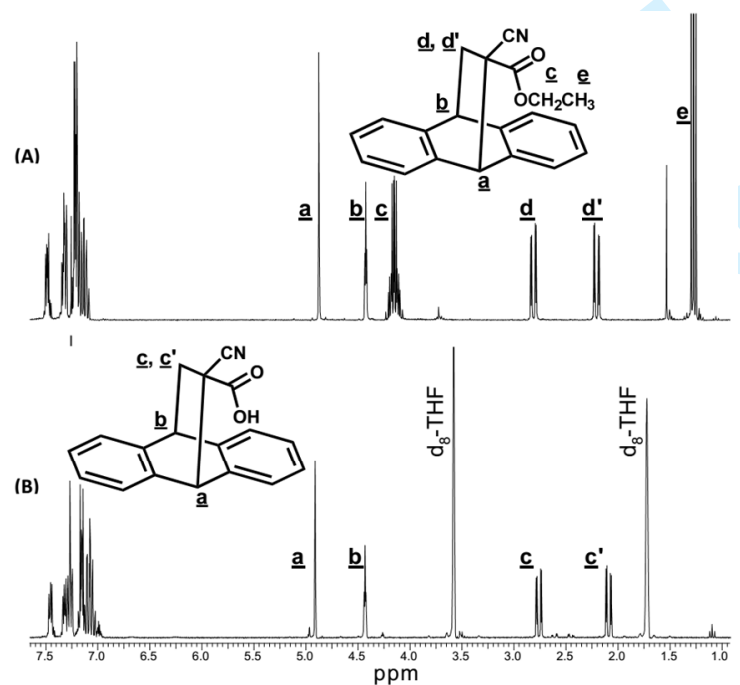

FIGURE $2{ }^{1} \mathrm{H}$ NMR spectra of (A) Ethyl-9,10dihydro-9,10-endoethanoanthracene-11-cyano11-carboxylate, anthracene-protected 2-cyano acrylic ethyl ester, and (B) 9,10-dihydro-9,10endoethanoanthracene-11-cyano-11-carboxylic acid, anthracene-protected 2-cyanoacrylic acid.

\section{Synthesis of $\varnothing(P I B-C A)_{3}$}

The preparation of $\varnothing(\mathrm{PIB}-\mathrm{CA})_{3}$ has been described. ${ }^{8,9}$ Briefly, the synthesis involves the living polymerization of isobutylene induced by a trifunctional initiator, and termination with allyltrimethyl silane. The 3-arm star allylterminated intermediate is converted quantitatively to the hydroxyl or bromine terminated intermediate, which is then reacted with anthracene-protected acryloyl chloride. ${ }^{8}$ or, preferentially, with 2-cyano acrylic acid. ${ }^{9}$

Earlier syntheses of $\varnothing(\text { PIB-CA })_{3}$ carried out by the use of (anthracene-protected) acryloyl chloride consistently gave yellow products. Efforts to remove the color (repeated precipitations, column chromatography, and treatment with activated carbon) were only partially successful. The source of the discoloration is unknown (most likely due to traces of impurities associated with the use of thionyl chloride). In contrast, esterification of $\varnothing(\mathrm{PIB}-\mathrm{OH})_{3}$ with anthracene-protected 2-cyano acrylic acid gave colorless products. ${ }^{10}$ The equation outlines this preferred method for the synthesis of $\varnothing(\mathrm{PIB}-\mathrm{CA})_{3}$ (The protective anthracene group, indicated by $A$ in the semicircle, can be readily removed by maleic anhydride):

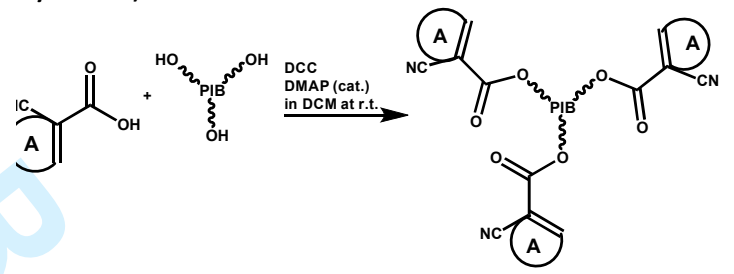

Thus, in a $50 \mathrm{~mL}$ Schlenk flask with a magnetic stir bar were placed under a blanket of nitrogen $\varnothing(\text { PIB-CA })_{3}\left(1.227 \mathrm{~g}, \mathrm{M}_{\mathrm{n}}=2500 \mathrm{~g} / \mathrm{mol}\right)$, anthracene-protected 2-cyano carboxylic acid adduct (1.333 g), and 4-dimethylamino pyridine (DMAP, $71.3 \mathrm{mg}$ ) dissolved in $25 \mathrm{~mL}$ dichloromethane (DCM). Then the solution was cooled to $0^{\circ} \mathrm{C}, \mathrm{N}, \mathrm{N}^{\prime}$-dicyclohexylcarbodiimide (DCC, $1.0648 \mathrm{~g}$ ) was added, the solution was stirred for $30 \mathrm{~min}$ at $0{ }^{\circ} \mathrm{C}$, and then overnight at room temperature. The precipitated urea was filtered off, the DCM was evaporated in vacuo, and the viscous residue was dissolved in THF and purified by two reprecipitations into methanol.

Finally, to yield $\varnothing(\mathrm{PIB}-\mathrm{CA})_{3}$, the protective anthracene group was removed by treatment with maleic anhydride in refluxing xylene for 8 hrs. According to NMR analysis the yields of protection and deprotection were typically $\sim 60$ 
and $\sim 90 \%$, respectively. Similar yields have been obtained by others who used the same protection/deprotection technique. ${ }^{11}$

Figure 3 shows the NMR spectra of the intermediates $(A-C)$ and of that of the target $\varnothing(\mathrm{PIB}-\mathrm{CA})_{3}(\mathrm{D})$ :

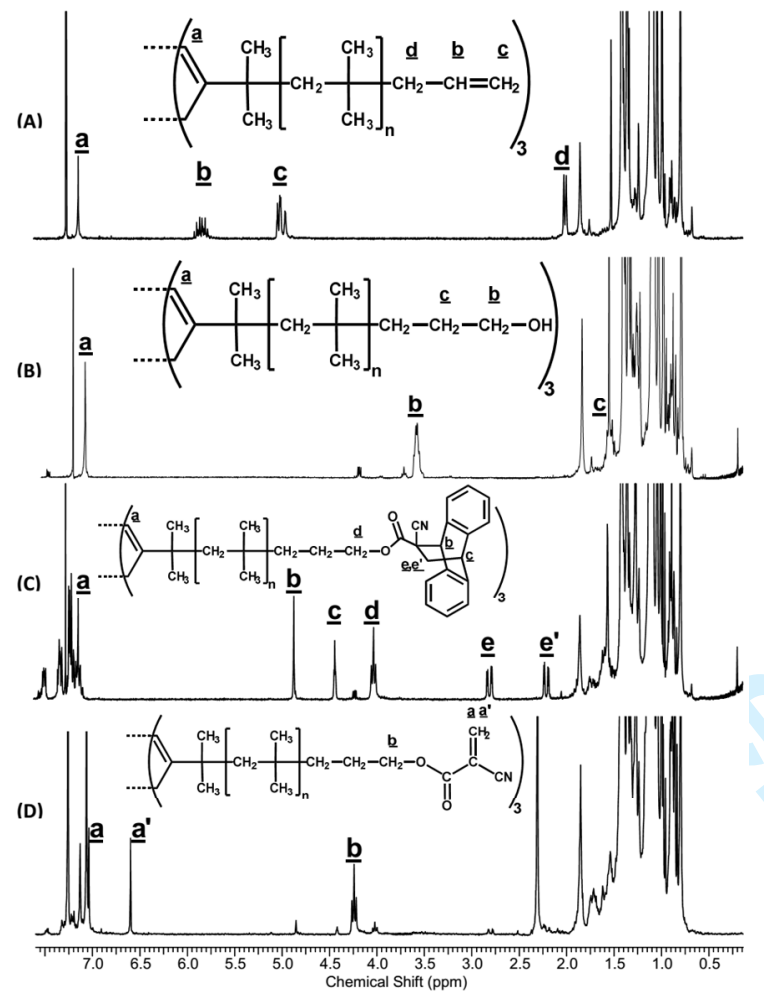

FIGURE $3{ }^{1} \mathrm{H}$ NMR spectra of $\varnothing(\mathrm{PIB}-\mathrm{CA})_{3}$ and intermediates: (A) allyl-, (B) hydroxyl-, (C) anthracene/cyanoacrylate adduct, and (D) cyanoacrylate-tri-telechelic PIB $\left[\varnothing(\mathrm{PIB}-\mathrm{CA})_{3}\right]$.

Figure 4 shows the GPC trace of the first intermediate, indicating a homogenous welldefined material with narrow molecular weight dispersity. GPC traces of the other intermediates were similarly narrow (not shown).

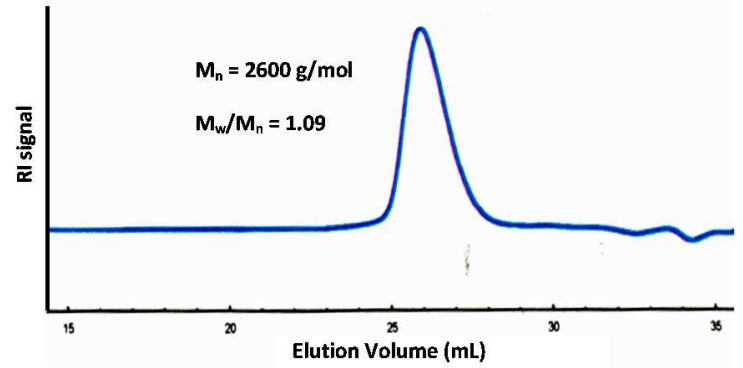

FIGURE 4 GPC trace of a representative threearm star allyl-tri-telechelic polyisobutylene, the starting material for $\varnothing$ (PIB-CA) $)_{3}$. (See $\mathbf{A}$ in Figure 3)

\section{Polymerization of neat OctCA}

A $5 \mathrm{~mL}$ vial containing a Teflon coated small (1 $\mathrm{cm})$ magnetic stir bar was charged with $1.0 \mathrm{~g}$ OctCA, and a calculated amount of DMT initiator was injected by a micro syringe. The charge turned yellow immediately upon DMT addition The vial was capped, vigorously mixed for a few seconds, and placed on a stirring plate for stirring at $\sim 60 \mathrm{rpm}$. The time (in seconds) stirring stopped due to the viscosity increase and gel formation was recorded (see also gel time experiments in the second paper in this series). The instant the gel formed the yellow color disappeared and the charge became colorless.

\section{Polymerization of OctCA with DMT diluted with THF}

Polymerizations were carried out under UHP nitrogen in $50 \mathrm{~mL}$ Schlenk flasks equipped with a magnetic stir bar. Flasks were sealed with a rubber septum, purged with nitrogen, flame dried, cooled to room temperature and charged with $1.938 \mathrm{~g} \quad(9.26 \mathrm{mmol})$ OctCA. Polymerizations were initiated by injecting DMT ( $0.1224 \mathrm{~g}, 0.905 \mathrm{mmol}$ ) dissolved in $4.9 \mathrm{~mL}$ THF under a blanket of $\mathrm{N}_{2}$ at r.t. $\left(\mathrm{M}_{0} / \mathrm{I}_{0}=10\right.$, [OctCA] $=1.32 \mathrm{~mol} / \mathrm{L})$. To keep the $[\mathrm{M}]_{0} /\left[\mathrm{I}_{0}\right.$ ratio constant, the volumes of OctCA $(0.5-1.2 \mathrm{~mL})$, and initiator solutions (5-100 $\mu \mathrm{L})$ were adjusted. The polymerization mixture became yellow immediately upon DMT addition. After $\sim 10 \mathrm{~min}$ 
stirring the yellow color disappeared and the mixture became colorless. After stirring overnight at room temperature the colorless polymer was purified by three precipitations in methanol and dried in vacuum at $60^{\circ} \mathrm{C}$ for $24 \mathrm{~h}$ to constant weight. Figure 5 shows the NMR spectrum of $\mathrm{P}(\mathrm{OctCA})$ together with assignments. The resonance at $4.26 \mathrm{ppm}$ (b) indicates the presence of $-\mathrm{OCH}_{2} \mathrm{CH}_{2}$ - groups.

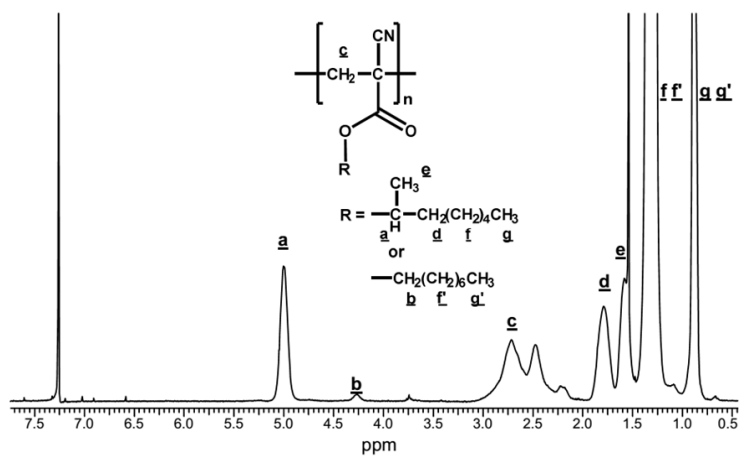

FIGURE $5{ }^{1} \mathrm{H}$ NMR spectrum of poly(2-octyl cyanoacrylate) (the polymer contains $\sim 2 \mathrm{~mol} \%$ of 1-octyl cyanoacrylate).

\section{Homopolymerization of $\varnothing(P I B-C A)_{3}$ and Copolymerization of $\varnothing(P I B-C A)_{3}$ with OctCA}

Homo-networks were prepared by polymerizing $\varnothing(\mathrm{PIB}-\mathrm{CA})_{3}$, and co-network by copolymerizing $\varnothing(\mathrm{PIB}-\mathrm{CA})_{3}$ and OctCA using DMT at room temperature. Thus, in a well-dried $10 \mathrm{~mL}$ screw-cap vial was placed $\varnothing$ (PIB-CA $)_{3}(0.3-1.2 \mathrm{~g}$, $\mathrm{Mn}=2400 \mathrm{~g} / \mathrm{mol}$ ) dissolved in $3 \mathrm{~mL}$ freshly distilled THF. Polymerizations were induced by adding various amounts $(5-150 \mu \mathrm{L})$ of DMT initiator. The vial was capped, the solution was vigorously manually agitated for 1-2 seconds and rapidly poured into a $7 \times 7 \mathrm{~cm}$ Teflon mold. The volatiles were evaporated in a fume hood for $1 \mathrm{hr}$, and the film was dried at $60{ }^{\circ} \mathrm{C}$ to constant weight.

Copolymerizations were carried out similarly, except desired amounts of OctCA were added to the $\varnothing(\mathrm{PIB}-\mathrm{CA})_{3}$ charge.

\section{RESULTS AND DISCUSSION}

\section{Alkyl Cyanoacrylates: Advantages - Disadvantages}

Alkyl CAs (particularly the lower alkyl derivatives) present a unique family of chemicals exhibiting a unique combination of properties. First and foremost, the CA group is highly reactive toward nucleophiles because of the presence of the two highly electron withdrawing substituents ( $\mathrm{CN}$ - and $\mathrm{COO}-$ ), so that CA polymerizations are initiated by the weakest of bases, e.g., water ${ }^{12,13}$; for instance, Me- and Et-CA instantaneously polymerize in the presence of surface moisture (Superglue). The rates of polymerizations are somewhat lower with the higher alkyl CAs (e.g., Bu-, OctCA) due to the lower molar concentration of the CA groups. Strong bases (e.g., tert. amines), quaternary ammonium salts, etc. rapidly induce the polymerization of $\mathrm{Bu}$ - and OctCA, and these CAs, upon contact with initiators dispensed from specially designed delivery devices, are clinically used wound closure adhesives. ${ }^{14}$ OctCA is the active ingredient of J\&J's (Ethicon) Dermabond $^{\circledR}$, and several other successful topical wound closure adhesives used by health professionals. ${ }^{15}$

Among the significant disadvantages of the lower alkyl CAs are their very low viscosity, brittleness/stiffness of their polymers, and the toxicity of their degradation products (e.g., formaldehyde). These CAs, when inadvertently dropped on the skin, travel rapidly and uncontrollably over surfaces (they are "runny"), enter into cuts or wounds where they polymerize, and the stiff polymer that forms in the wound retards healing. To overcome this disadvantage, some contemporary wound adhesives are formulated with viscosity enhancing additives (e.g., Advanced Dermabond $^{\circledR}$ ).

While the inherent reactivity of the CA group is extremely high toward nucleophiles, and Meand EtCA polymerize virtually instantaneously in the presence of even traces of water, the rate of polymerizations of higher alkyl CAs is lower (see above). For instance, while Me- or Et-CA become stiff solids ("set") within seconds after 
contacting nucleophiles, we found that OctCA requires several (6-8) minutes to reach the same consistency. Thus, OctCA requires the use of reactive initiators (e.g., amines, quaternary ammonium salts) in practical wound closure adhesives.

Polymers (films, coatings) that arise from the lower alkyl CAs are undesirably brittle/stiff for wound closure applications and are not used over moving skin or skin in tension. The glass transition temperatures of these polymers reflect the extent of their brittleness: $\mathrm{T}_{\mathrm{g}, \mathrm{Me}-\mathrm{CA}_{\mathrm{A}}=}$ $165^{16}, \mathrm{~T}_{\mathrm{g}, \mathrm{EtCA}}=140, \mathrm{~T}_{\mathrm{g}, \mathrm{BuCA}}=90^{17}$, and $\mathrm{T}_{\mathrm{g}, \mathrm{OctCA}}=$ $39.8{ }^{\circ} \mathrm{C}^{18}$ Over naturally moving skin and/or skin creases, these stiff adhesives tend to slough off and leave the wound unprotected. Thus, due to their lack of flexibility, the polymers of lower alkyl CAs are unsuitable for wound closure over the knee, elbow, knuckles, etc. We theorized that networks and conetwork containing rubbery $\varnothing(\mathrm{PIB}-\mathrm{CA})_{3}$ would be inherently flexible and therefore superior in these applications.

In regard to toxicity, poly(Et-CA) degrades, among other things, to formaldehyde, whose toxicity raises serious health issues as tissue adhesive. ${ }^{19}$ The toxicity of CAs decreases with the length of the alkyl chain ${ }^{20,21}$, and BuCA and OctCA are FDA approved topical skin adhesives.

\section{Polymerizations and Product Characterization}

\section{Polymerization of OctCA to Thermoplastics}

Figure 6 shows the repeat structure of $\mathrm{P}$ (OctCA).

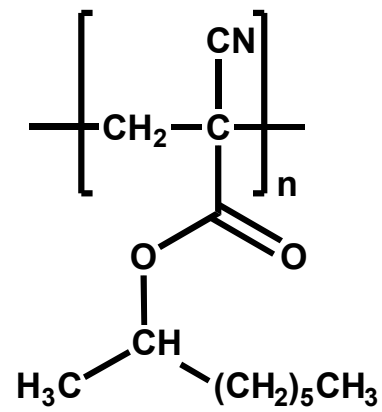

FIGURE 6 The Repeat Structure of Poly(2-octyl cyanoacrylate)
$\mathrm{P}$ (OctCA) is an optically transparent rather stiff thermoplastic $\left(T_{\mathrm{g}} \sim 59^{\circ} \mathrm{C}\right.$, see Figures 13 and 14$)$, with high permanent set and a strong tendency to creep (see Figure 8). Thus, P(OctCA) tends to slough off the skin rather rapidly after deployment. Due to its stiffness it is not recommended for use over moving or creased skin.

\section{Polymerization of $\varnothing(P I B-C A)_{3}$ to Rubbery Networks}

$\varnothing(\text { PIB-CA })_{3}$ upon contact with nucleophiles (initiators, proteinaceous tissue, moisture) crosslinks and yields networks. ${ }^{9,22}$ The extent and rate of crosslinking depend on the length (molecular weight) of the PIB arms (i.e., the molar concentration of CA groups), and the nature and quantity of the initiator employed. Table 1 shows the amount of extractables obtained with representative PIB-based homoand co-network prepared with $\varnothing(\mathrm{PIB}-\mathrm{CA})_{3}$ of $\mathrm{Mn}=2400$ and CA-PIB-CA of $4000 \mathrm{~g} / \mathrm{mol}$ by the use of DMT initiator. The small amounts of extractables (3-5\%) indicate extensive network formations. It is of interest that co-networks prepared with linear terminally bifunctional CAPIB-CAs plus OctCA also gave highly crosslinked networks (see Entries 2 and 3).

TABLE 1 Extractables of Representative Networks and Co-network.

\begin{tabular}{|c|c|c|}
\hline Sample & Composition, $M_{n}$, wt \% & $\begin{array}{c}\text { Extractables } \\
\text { (wt\%) }\end{array}$ \\
\hline \multicolumn{3}{|c|}{ Homo-networks } \\
\hline 1. & $100 \% \varnothing(\mathrm{PIB}-\mathrm{CA})_{3}\left(\mathrm{M}_{\mathrm{n}}=2400 \mathrm{~g} / \mathrm{mol}\right)$ & 3.1 \\
\hline \multicolumn{3}{|c|}{ Co-networks } \\
\hline 2. & $\begin{array}{c}\text { CA-PIB-CA }\left(\mathrm{M}_{\mathrm{n}}=4000 \mathrm{~g} / \mathrm{mol}\right) / \mathrm{OctCA} \\
27 / 73\end{array}$ & 5.1 \\
\hline 3. & $\begin{array}{c}\text { CA-PIB-CA }\left(\mathrm{M}_{\mathrm{n}}=4000 \mathrm{~g} / \mathrm{mol}\right) / \mathrm{OctCA} \\
49 / 51\end{array}$ & 3.7 \\
\hline 4. & $\begin{array}{c}\varnothing(\mathrm{PIB}-\mathrm{CA})_{3}\left(\mathrm{M}_{\mathrm{n}}=2400 \mathrm{~g} / \mathrm{mol}\right) / \mathrm{OctCA} \\
25 / 75\end{array}$ & 3.7 \\
\hline 5. & $\begin{aligned} & \varnothing(\mathrm{PIB}-\mathrm{CA})_{3}\left(\mathrm{M}_{\mathrm{n}}=\right.2400 \mathrm{~g} / \mathrm{mol}) / \mathrm{OctCA} \\
& 49 / 51\end{aligned}$ & 5.1 \\
\hline
\end{tabular}

Copolymerization of $\varnothing(P I B-C A)_{3}$ with OctCA to Rubbery Co-networks 
Prior to bulk copolymerizations, the mutual miscibility of $\varnothing(\mathrm{PIB}-\mathrm{CA})_{3}$ and OctCA was investigated. We found that OctCA and $\varnothing$ (PIBCA) ${ }_{3}$ of $M_{n}=2400 \mathrm{~g} / \mathrm{mol}$ yield optically clear blends in all proportions, indicating that OctCA and $\varnothing(\mathrm{PIB}-\mathrm{CA})_{3}$ are miscible. In contrast, even small amounts ( $5 \%)$ of Me- and EtCA are immiscible with $\varnothing(\mathrm{PIB}-\mathrm{CA})_{3}$ and yield hazy mixtures under the same conditions. The optical transparency of the film substantiates miscibility (see Figure 7).

\section{CO-NETWORKS}

\section{CO-NETWORKS}

\section{CO-NETWORKS}

FIGURE 7 Transparency of a Sheet of 25\% $\varnothing(\mathrm{PIB}-\mathrm{CA})_{3}\left(\mathrm{M}_{\mathrm{n}}=2400 \mathrm{~g} / \mathrm{mol}\right)-\mathrm{co}-75 \% \mathrm{P}(\mathrm{OctCA})$

\section{Physical Properties of Co-networks}

\section{Static and Dynamic Mechanical Properties}

Figure 8 shows stress-strain profiles of a $\mathrm{P}$ (OctCA), a homo-network made by crosslinking neat $\varnothing(\mathrm{PIB}-\mathrm{CA})_{3}$, and several representative $\varnothing$ (PIB-CA $)_{3}$-co-OctCA co-networks . The stressstrain profiles of $\mathrm{P}$ (OctCA) and the homonetwork exhibit quite weak (barely $1 \mathrm{MPa}$ ) rubbery and thermoplastic behavior, respectively, and are fundamentally different from those of the co-networks. Importantly, the strength of the homo-network increases upon OctCA incorporation, and the co-networks are tough rubbers with 2-4.5 $\mathrm{MPa}$ tensile strength and up to $70 \%$ ultimate elongation.

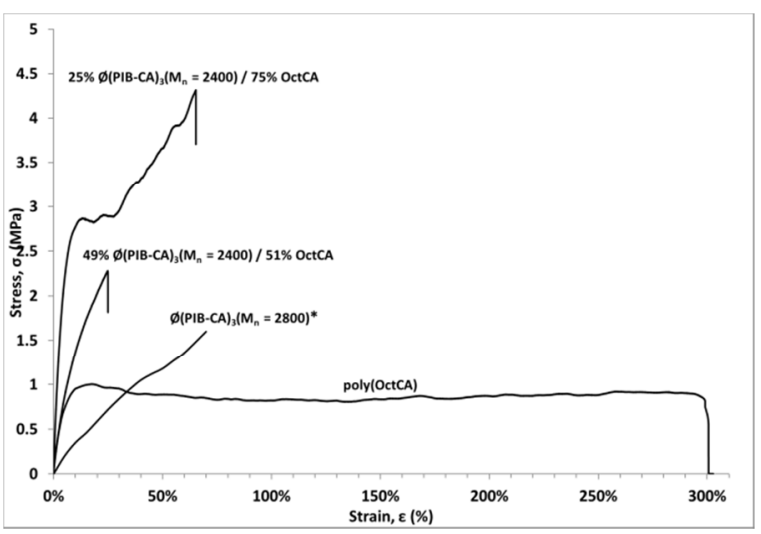

FIGURE 8 Stress-strain traces of a P(Oc-CA), a $\varnothing(\mathrm{PIB}-\mathrm{CA})_{3}$ homo-network, and representative $\varnothing(\mathrm{PIB}-\mathrm{CA})_{3}-\mathrm{CO}-\mathrm{P}$ (Oc-CA) co-networks. (Molecular weights and compositions indicated. ${ }^{*}$ From ref. 8)

It is difficult to obtain accurate physical properties (i.e., tensile, elongation, etc.) of human skin. For example, according to Holzappel. ${ }^{23}$ human skin, depending on location, exhibits 1-20 MPa tensile strength and $30-70 \%$ ultimate elongation. Figure 9 shows that a representative $\varnothing(\mathrm{PIB}-\mathrm{CA})_{3}$-co-P(OctCA)'s strength matches and its elongation far exceeds that of human skin.

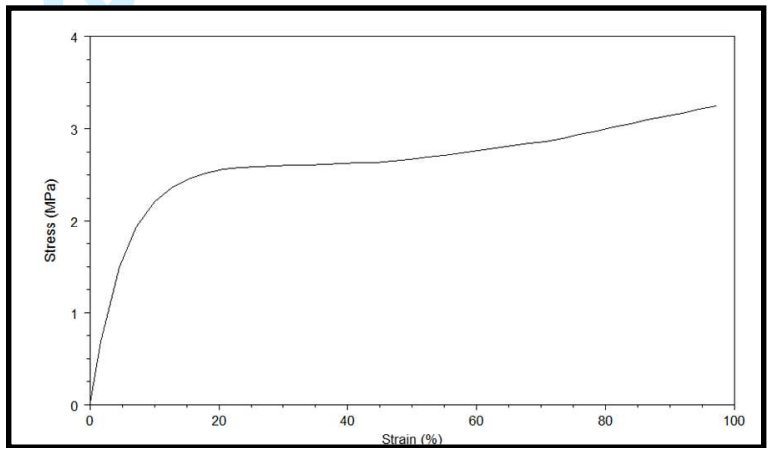

FIGURE 9 Stress-strain trace of a co-network of $25 \% \varnothing(\text { PIB-CA })_{3} \quad\left(M_{n}=2400 \mathrm{~g} / \mathrm{mol}\right)-\mathrm{co}-75 \%$ $\mathrm{P}($ OctCA $)$, at $30^{\circ} \mathrm{C}$.

Creep is time-dependent plastic deformation that occurs under stresses lower than yield stress. Stress relaxation and creep are both due to uncoiling/disentangling of soft/rubbery materials, and yield essentially identical data in regard to time dependent deformation. Low 
stress relaxation rates indicate low creep and vice versa. Creep strain and recovery versus time profiles give important information in regard to a material's creep resistance. The creep test recommended by the FDA is useful to evaluate the mechanical performance of topical skin closures $^{24}$ Figure 10 shows such data for the $25 / 75 \%$ co-network at two different loads.

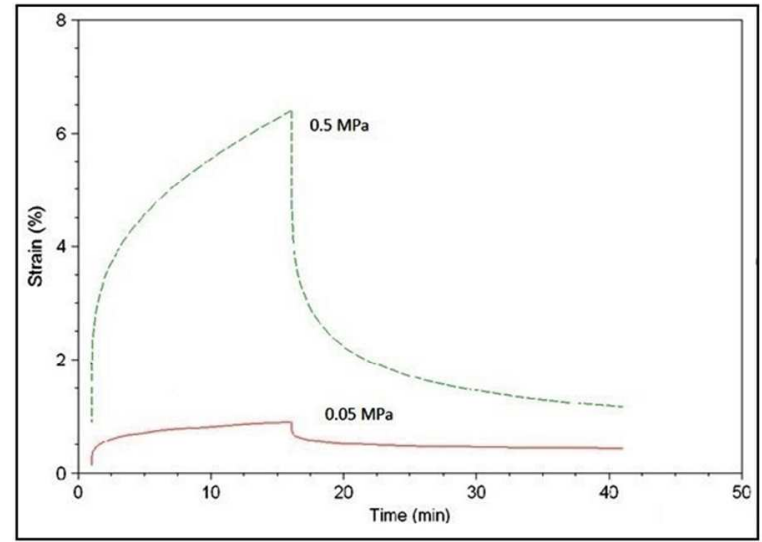

FIGURE 10. Tensile creep strain versus test time for a $25 \% \varnothing(\mathrm{PIB}-\mathrm{CA})_{3}\left(\mathrm{M}_{\mathrm{n}}=2400 \mathrm{~g} / \mathrm{mol}\right)-\mathrm{co}-75 \%$ $\mathrm{P}$ (OctCA) co-network, at $30^{\circ} \mathrm{C}$.

This rubbery co-network exhibits high dimensional stability and quite low creep strain ( 6\%) even at high loading (0.5 MPa). Indeed, the material shows only $\sim 1 \%$ permenant deformation at high load. At lower tension (0.05 $\mathrm{MPa}$ ), deformation and permanent deformation decrease to 0.8 and $0.3 \%$, respectively, which may be due to restriction of slippage, reorientation, and motion of chains within dispersed $\mathrm{P}$ (OctCA) hard domains.

The time-temperature superposition (TTS) method extends the range of frequencies or times of viscoelastic properties beyond measurable quantities, and provides a unique way of estimating viscoelastic properties over time. We used TTS to determine the long-term properties of a rubbery co-network held under stress. Figure 11 shows the variation of creep strain with time at different temperatures.

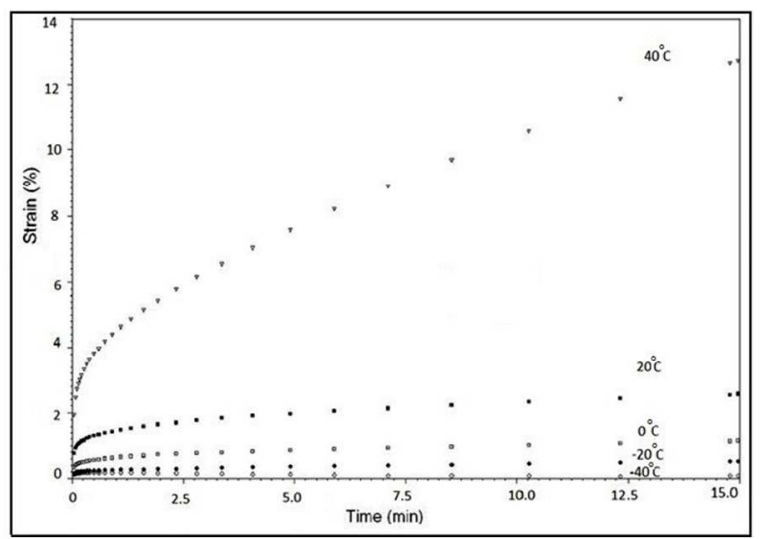

FIGURE 11 Creep curves for a 25\% $\varnothing(\text { PIB-CA })_{3}$ $\left(\mathrm{M}_{\mathrm{n}}=2400 \mathrm{~g} / \mathrm{mol}\right)$-co-75\% P(OctCA) co-network at various temperatures.

As relaxation accelerates with temperature, creep strain increases with temperature, and samples deform under stress producing higher strain. A master curve was prepared by using $0{ }^{\circ} \mathrm{C}$ as the reference temperature and shifting the data by the software. The data obtained ranged from approximately 0.1 to $250,000 \mathrm{~min}$ (ca. 6 months). Figure 12 shows the data for 35 days since the maximum use of a wound closure will not exceed $\sim 9$ days due to various safety issues, time dependent irritation, sensitizing, infection, etc. ${ }^{25}$

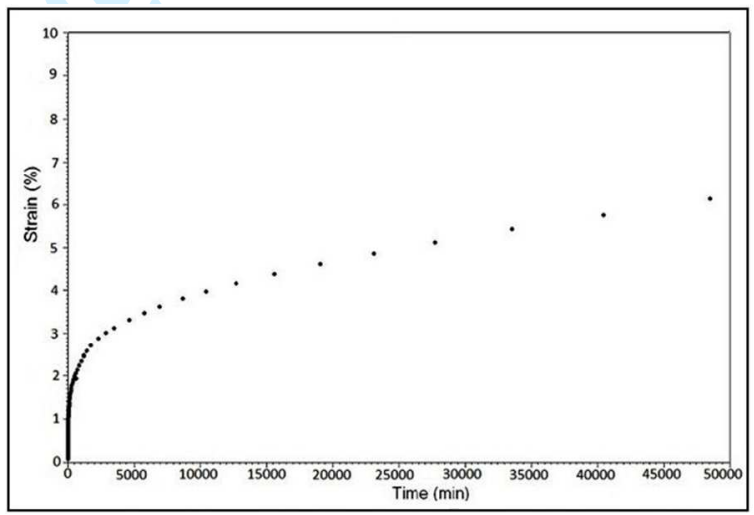

FIGURE 12 TTS master curve for a 25\% $\varnothing$ (PIB$\mathrm{CA})_{3}\left(\mathrm{M}_{\mathrm{n}}=2400 \mathrm{~g} / \mathrm{mol}\right)-$ co- $75 \% \mathrm{P}($ OctCA $)$ conetwork.

Evidently, this new rubbery wound closure exhibits excellent mechanical and use properties, such as creep and short and long term physical stability. 


\section{Thermal Properties}

Examination of thermal transitions provides valuable insight into the structure of polymeric materials. Figure 13 show the DSC trace of a $25 \% \varnothing(\mathrm{PIB}-\mathrm{CA})_{3} \quad\left(\mathrm{M}_{\mathrm{n}}=2400 \mathrm{~g} / \mathrm{mol}\right)-\mathrm{co}-75 \%$ $\mathrm{P}$ (OctCA) co-network with the expected two main transitions: the glass transition temperature of the soft PIB phase at $\sim-18{ }^{\circ} \mathrm{C}$ and that of the hard $\mathrm{P}(\mathrm{OctCA})$ at $\sim 59^{\circ} \mathrm{C}$.

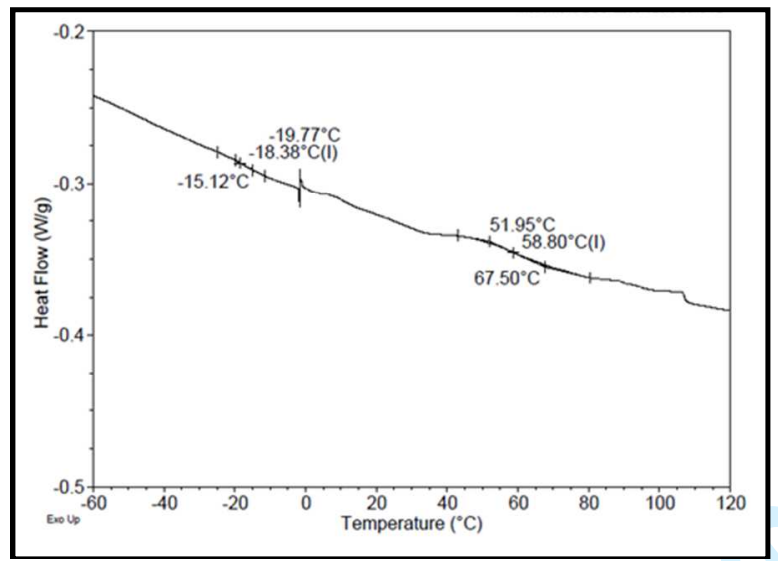

FIGURE 13 DSC trace of $25 \% \varnothing(\mathrm{PIB}-\mathrm{CA})_{3}\left(\mathrm{M}_{\mathrm{n}}=\right.$ $2400 \mathrm{~g} / \mathrm{mol})-$ co-75\% P(OctCA) co-network.

Earlier workers reported $\mathrm{T}_{\mathrm{g}}=-38{ }^{\circ} \mathrm{C}$ and $40{ }^{\circ} \mathrm{C}$ for a homo-network of $\varnothing(\mathrm{PIB}-\mathrm{CA})_{3}{ }^{22}$, and $\mathrm{P}$ (OctCA) ${ }^{18}$, respectively. In the co-network under investigation, the PIB transition is shifted toward higher temperatures and covers a wide temperature range, which is characteristic of a rubber-toughened plastic. The upward shift may be due to the crosslinks restricting the motion of the soft phase, which leads to increased phase compatibility. In regard to the $\mathrm{T}_{\mathrm{g}}$ of $\mathrm{P}$ (OctCA) the reader is directed to the comment in ref. 18.

These transitions also appear in the DMTA traces of this co-network (see Figure 14).

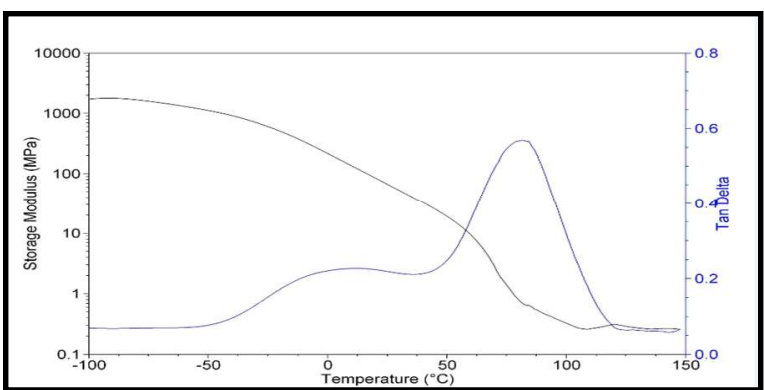

FIGURE 14 DMTA traces of a representative $25 \% \varnothing(\mathrm{PIB}-\mathrm{CA})_{3}\left(\mathrm{M}_{\mathrm{n}}=2400 \mathrm{~g} / \mathrm{mol}\right)-\mathrm{co}-75 \%$ $\mathrm{P}$ (OctCA) co-network.

The storage modulus ( $\left.E^{\prime}\right)$ indicates a welldefined low and high temperature flow region, associated with two phases, and exhibits a rather high modulus ( $100 \mathrm{MPa})$, dynamic conditions $1 \mathrm{~Hz}$ at room temperature. Evidently, this co-network is an efficient load bearing material even under dynamic conditions.

The two tan delta peaks indicate a low $\left(\sim-5{ }^{\circ} \mathrm{C}\right)$ and a high $\left(\sim 75{ }^{\circ} \mathrm{C}\right)$ temperature transition corresponding to PIB and crosslinked P(OctCA) phases, respectively. The $\mathrm{T}_{\mathrm{g}}$ 's are higher than literature values because the dynamic technique yields higher values than DSC, and because the presence of a limited amount of $\mathrm{PIB}$ in an extensively crosslinked co-network. This $\varnothing(\mathrm{PIB}-\mathrm{CA})_{3}$-co-P(OctCA) is an effective damper over a wide temperature range $(-50$ to $120{ }^{\circ} \mathrm{C}$ ). Similar observations have been reported for PIB-based co-networks with EtCA. $^{26}$

\section{Polymer Chemical Considerations}

Since the inherent reactivity of a functional group (in this instance the CA group) is independent of the molecular weight of the polymer it is attached to, it may be safely assumed that the reactivities of the CA groups of OctCA and $\varnothing(\text { PIB-CA })_{3}$ are essentially identical (i.e., their reactivity ratios are unity). Thus, the compositions of co-network are controllable by controlling the relative amounts of OctCA and $\varnothing(\mathrm{PIB}-\mathrm{CA})_{3}$ in these miscible charges.

In the presence of a stoichiometric excess of OctCA in a OctCA $\varnothing(\text { PIB-CA })_{3}$ charge assembled for the synthesis of co-network, initiation will 
preferentially involve OctCA. According to several literature sources ${ }^{12,} 27-32$ the first event of initiation is Michael addition of DMT to OctCA:

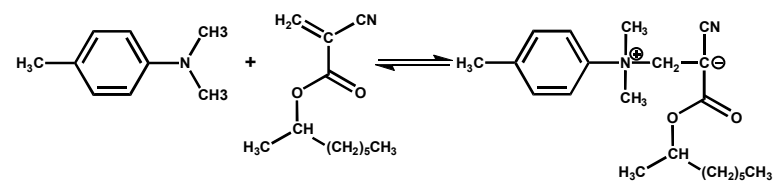

If this were true the polymer ought to carry the DMT head group. We searched for but were unable to identify aromatic head groups in polymers prepared with DMT (see also the second publication in this series). In spite of extensive research in this field by earlier workers $^{27-29}$, the exact details of initiation (better, the initial phase) of anionic alkyl cyanoacrylate polymerization remain unknown.

During the early stages of polymerization the viscosity of the system is relatively low and propagation, i.e., the attack of the first $C A$ anion to OctCA and/or $\varnothing(\mathrm{PIB}-\mathrm{CA})_{3}$ (that yields crosslinking) is relatively unhindered:

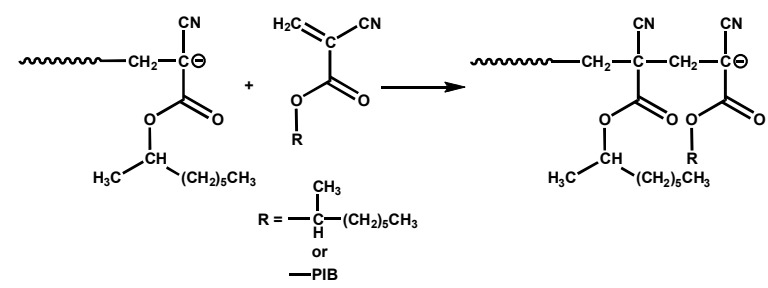

Upon further propagation steps, particularly after $\varnothing(\mathrm{PIB}-\mathrm{CA})_{3}$ incorporation, the viscosity of the system rises very rapidly and the rate of (co)polymerization drops precipitously. Ultimately, a fraction of CA groups likely become entrapped in the highly viscous matrix and propagation ceases (see "useless" CAs in Figures15 and 16).

Due to the highly hydrophobic matrix, termination, i.e., the permanent annihilation of propagating anions, which likely involves reaction with protons (i.e., moisture), is absent or is very slow in these bulk systems. Pepper, on the basis of kinetic studies, also proposed absence of termination in similar CA polymerizations. ${ }^{33,34}$
The mechanical properties of the products may be controlled by controlling the relative proportions of the rubbery PIB and glassy $P(O c t C A)$ segments. Increasing the length of the PIB arms increases elongations and decreases moduli. The longer $\mathrm{P}(\mathrm{OctCA})$ sequences would phase separate and may function as reinforcing sites. Ultimate properties could also be controlled by the use of mixtures of two (or more) $\varnothing(\mathrm{PIB}-\mathrm{CA})_{3} \mathrm{~s}$ of different $\mathrm{M}_{\mathrm{n}}{ }^{\prime} \mathrm{s}$, or blends of $\varnothing(\mathrm{PIB}-\mathrm{CA})_{3} \mathrm{~s}$ with linear telechelic CA-PIB-CAs.

\section{Microstructure/Morphology}

Figure 15 is a sketch of an idealized microstructure of a homo-network formed by the polymerization of $\varnothing$ (PIB-CA $)_{3}$ deposited on proteinaceous surface (skin). These constructs are in fact PIB networks (the CA groups merely provide initiating and crosslinking sites) with two kinds of crosslinking sites: (a) the aromatic centers of the $\varnothing(\mathrm{PIB}-\mathrm{CA})_{3}$, and (b) crosslinks formed by linking two (or less likely three or more) CA groups. Polymerizations may be induced by the initiator (I), nucleophilic groups, or adsorbed moisture on the surface of the skin. The networks are expected to contain numerous loops and catenates, which affect ultimate load bearing properties.

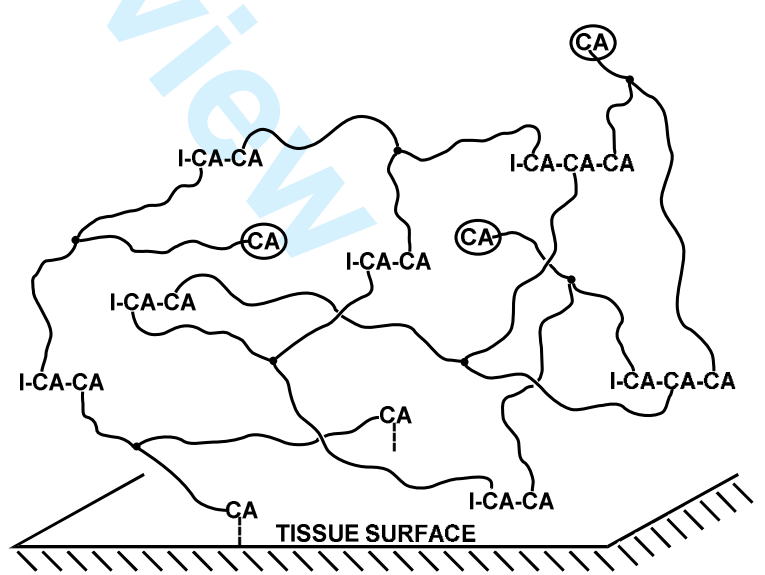

FIGURE 15 Idealized microstructure of a rubbery PIB homo-network formed of $\varnothing$ (PIB$\mathrm{CA})_{3}$. $($ Wiggly lines $=\mathrm{PIB}, \mathrm{I}=$ initiator; $\bullet$ =aromatic center of $\varnothing(\mathrm{PIB}-\mathrm{CA})_{3}, \mathrm{CA}---=\mathrm{CA}$ bonded to skin surface, $C A$ in circles = "useless" entrapped CA). 
Note the loops and entrapped/catenated crosslinks.

Figure 16 helps to visualize an idealized microstructure of a $\varnothing$ (PIB-CA $)_{3}$-co-P(OctCA) conetwork that arises from a homogeneous 50/50 wt/wt blend of OctCA plus $\varnothing(\text { PIB-CA })_{3}$ upon the addition of an initiator in bulk at room temperature. In these co-networks the $\mathrm{P}$ (OctCA) sequences are of sufficient length to form separate coalesced phases whose $T_{g}$ can be identified by appropriate instrumentation (see DSC and DMTA data above).

(A note on nomenclature: These co-networks may also be abbreviated $\mathrm{P}\left(\right.$ OctCA)-I- $\varnothing(\mathrm{PIB}-\mathrm{CA})_{3}$, where I stands for "crosslinked by", signifying $\mathrm{P}$ (OctCA) chains crosslinked by 3-arm star CAtelechelic PIB macromonomers)

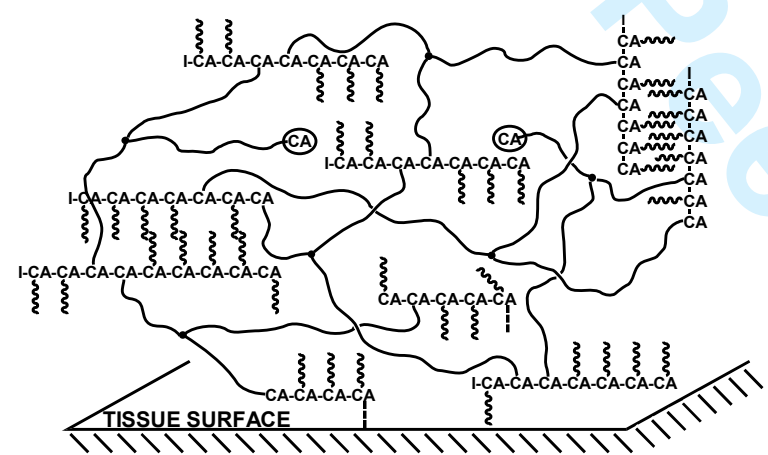

FIGURE 16 Idealized structure of a 50/50 wt/wt $\varnothing(\mathrm{PIB}-\mathrm{CA})_{3}-\mathrm{co}-\mathrm{P}$ (OctCA) co-network. (Wiggly line $=P I B, I=$ initiator, $C A---=C A$ bonded to skin surface, $C A$ in circle $C A=$ "useless" CA groups entrapped in matrix, $\bullet=$ aromatic center of $\varnothing(\mathrm{PIB}-\mathrm{CA})_{3}$. Note the presence of catenated/entrapped crosslinks and PIB loops. The polymerization of CA groups is initiated by a purposely added initiator (I), or a nucleophilic group ( $\mathrm{N}$ or $\mathrm{O}$ ) in the epidermis,(---), or by traces of moisture.

\section{Cytotoxicity of $\varnothing(\mathrm{PIB}-\mathrm{CA})_{3}-\mathrm{co}-\mathrm{P}(\mathrm{OctCA})$}

Incubation of fibroblasts with $1 \mathrm{X}$ MEM extracts of a representative $\varnothing$ (PIB-CA $)_{3}-\mathrm{Co}-\mathrm{P}(\mathrm{OctCA}) \mathrm{co}-$ network did not lead to cell growth inhibition or cell lysis in any of the test wells ( $0 \%$ rounded cells, $0 \%$ cells with intracytoplasmic granules, and $0 \%$ cell lysis). No $\mathrm{pH}$ shift was observed at 48 hours. Co-network extracts met the requirements of the test (ISO 10993-5) as the grade was equal to or less than grade 2 (i.e., not more than $50 \%$ round cells, no intracytoplasmic granules, no cell lysis, and not more than 50\% growth inhibition).

\section{CONCLUSIONS}

Neat $\varnothing(\mathrm{PIB}-\mathrm{CA})_{3}$, and $\phi(\mathrm{PIB}-\mathrm{CA})_{3}-\mathrm{CO}-\mathrm{P}(\mathrm{OctCA})$, upon contact with DMT initiator, produce rubbery homo- and co-networks of potential use as occlusive flexible wound closure adhesives. A variety of such networks have been prepared, characterized by various techniques, and select properties, e.g., elongation, tensile strength, creep, were determined. It seems that co-networks comprising $25 \% \varnothing(\mathrm{PIB}-\mathrm{CA})_{3}(\mathrm{Mn}=2400 \mathrm{~g} / \mathrm{mol})$ and $75 \% \mathrm{P}$ (OctCA) exhibit superior extensibility and strength than skin, rendering these materials potential wound closure adhesives. According to short and long term creep studies these co-networks exhibit high dimensional stability and low creep strain ( $6 \%$ ) even at high loading. Co-network extracts showed no evidence of cell lysis or toxicity. In respect to application, viscous co-networks upon contact with appropriate amounts of DMT polymerize within seconds and produce strongly adherent transparent rubbery coatings on porcine skin. The coatings follow the contours and irregularities of the skin, giving rise to smooth rubbery flexible transparent membranes, which adhere strongly to the surface and provide seamless hermetic closures. Strips of porcine skin coated with select co-networks could be repeatedly stretched, flexed and twisted without compromising the integrity of the membrane. As P(alkyl CA)s have poor resistance to prolonged contact with water ${ }^{32}$, and the adhesive bond between P(alkyl CA)s and skin is loosened by soaking in warm water ${ }^{35}$, it is remarkable that $\varnothing(\mathrm{PIB}-\mathrm{CA})_{3}-\mathrm{co}-\mathrm{P}$ (OctCA) coatings remained strongly adherent to strips of porcine skin even after many months of soaking in water. 


\section{ACKNOWLEDGEMENTS}

We wish to thank $\mathrm{Dr}$ lan McCollough for literature searches, and Dr Hongyi Yuan for help in mechanical testing of materials.

\section{REFERENCES AND NOTES}

1. J. P. Kennedy, Macromol. Symp. 2001, 175(II), 127-131.

2. J. E. Puskas, Y. Chen, Y. Dahman, D. Padavan, J. Polym. Sci. Part A: Polym. Chem. 2004, 42 (13), 3091-3109.

3. J. E. Puskas,; Y. Chen, Biomacromolecules 2004, 5(4), 1141-1154.

4. J. P. Kennedy, and B. Ivan, Designed Polymers by Carbocationic Macromolecular Engineering: Theory and Practice; Hanser Pub.: New York and Munich, 1992.

5. M. K. Mishra, J. P. Kennedy, Desk Reference of Functional Polymers; R. Arshady, Ed; ACS: Washington DC. 1997, pp 57-72.

6. C. Lherm, R. H. Muller, F. Puisieux, P. Couvreur, Int. J. Pharm. 1992, 84(1), 13-22.

7. D. H. Park, S. B. Kim, K.-D. Ahn, E. Y. Kim, Y. J. Kim, D. K. Han, J. Appl. Polym. Sci. 2003, 89(12), 3272-3278.

8. Y. Kwon, J. P. Kennedy, Polym. Advan. Technol. 2007, 18, 800-807.

9. J. P. Kennedy, S. Midha, A. Gadkari, J. Macromol. Sci. Chem. 1991, A28(2), 209-224.

10. B. Neises, W. Steglich, Angew. Chem. Int. Edit. 1978, 17(7), 522-524.

11. C. J. Buck, J. Polym. Sci.: Polym. Chem. Ed. 1978, 16(10), 2475-2507.

12. E. F. Donnelly, D. S. Johnston, D. C. Pepper, D. J. Dunn, J. Polym. Sci. Pol. Lett. 1977, 15, 399405.

13. I. C. Eromosele, D. C.; Pepper, B. Ryan, Makromolekul. Chem. 1989, 190, 1613-1622.

14. H. Liu, (Ethicon, Inc). U.S. Patent. $8,475,825$, July 2, 2013.

15. Topical Wound Closure Adhesives, see K100423 in http://www.accessdata.fda.gov/scripts/cdrh/cf docs/cfpmn/cfm
16. A. J. Canale, W. E. Goode, J. B. Kinsinger, J. R. Panchak, R. L. Kelso, R. K. Graham, J. Appl. Polym. Sci. 1960, 4(11), 231-236.

17. Z. Denchev, M. Tomanova, A. Lederer, J. Polym. Sci. Part A: Polym. Chem. 2008, 46, 5142-5156.

18. L. Halliwell, Investigation and synthesis of alkyl cyanoacrylates and modification of X-ray contrast agents for incorporation into alkyl cyanoacrylate for use in medical devices. Ph.D. Thesis, University of Warwick, U.K. 2012. Although this thesis quotes a $\mathrm{T}_{\mathrm{g}}=39.8^{\circ} \mathrm{C}$ for poly(Oc-CA) obtained by Denchev et al., (ref .17), examination of the original source does not contain this datum.

19. P. A. Leggat, D. R. Smith, U. Kedjarune, ANZ J. Surg. 2007, 77, 209-213.

20. R. H. Muller, C. Lherm, J. Herbort, P. Couvreur, Biomaterials. 1990, 11, 590-595.

21. Y.-C. Tseng, Y. Tabata, S.-H. Hyon, Y. Ikada, J. Biomed. Mater. Res. 1990, 24(10), 1355-1367.

22. S. K. Jewrajka, J. P. Kennedy, J. Polym. Sci. Part A: Polym. Chem. 2008, 46, 2612-2623.

23. G.A. Holzapfel, "Biomechanics of Soft Tissue" in Handbook of Material Behaviour Nonlinear Models and Properties, Eds. Jean Lemaitre, LMT-Cachan, France, Academic Press, 2000

24. Guidance for Industry an FDA Staff- Class II Special Controls Guidance Document: Tissue Adhesive with Adjunct Wound Closure Device Intended for the Topical Approximation of Skin.in

http://www.fda.gov/MedicalDevices/DeviceReg ulationandGuidance/GuidanceDocuments/ucm 072424.htm

25. M. Rippon, R. White, P. Davies, Wounds UK. , 2007, 3(4), 76-86.

26. Y. Kwon, J. P. Kennedy, Polym. Advan. Technol. 2007, 18, 808-813.

27. D. S. Johnston, D. C. Pepper, Makromol. Chem. 1981, 182, 393-406.

28. D. S. Johnston, D. C. Pepper, Makromol. Chem. 1981, 182, 407-420.

29. D. S. Johnston, D. C. Pepper, Makromol. Chem. 1981, 182, 421-435.

30. J.P. Cronin, D. C. Pepper, Makromol. Chem. 1988, 189, 85-102. 
31. M. G. Han, WS. Kim, S. X. Liu, Polym. Deg. Stab. 2008, 93, 1243-1251.

32. D. R. Robello, T. D. Eldridge, M. T. Swanson, J. Polym. Sci. Part A: Polym. Chem. 1999, 37, 4570-4581.

33. D. C. Pepper, Polym. J. 1980, 12(9), 629-637.

34. D. C. Pepper, B. Ryan, Makromol. Chem.

1983, 184, 395-410.
35. P. Klemarczyk, In Adhesion Science and Engineering: Surfaces, Chemistry and Applications; M. Chaudhury, A. V. Pocius, Eds.; Elsevier: Amsterdam, 2002; Vol. 2, Chapter 19, pp 847-867. 
TABLE 1 Extractables of Representative Networks and Co-network.

\begin{tabular}{|c|c|c|}
\hline Sample & Composition, $\mathbf{M}_{\mathbf{n}}$, wt \% & $\begin{array}{c}\text { Extractables } \\
(\mathbf{w t} \%)\end{array}$ \\
\hline Homo-networks & 3.1 \\
\hline \multicolumn{2}{|c|}{$100 \% \varnothing(\mathrm{PIB}-\mathrm{CA})_{3}\left(\mathrm{M}_{\mathrm{n}}=2400 \mathrm{~g} / \mathrm{mol}\right)$} & \\
\hline Co-networks & 5.1 \\
\hline 2. & CA-PIB-CA $\left(\mathrm{M}_{\mathrm{n}}=4000 \mathrm{~g} / \mathrm{mol}\right) / \mathrm{OctCA} 27 / 73$ & 3.7 \\
\hline 3. & CA-PIB-CA $\left(\mathrm{M}_{\mathrm{n}}=4000 \mathrm{~g} / \mathrm{mol}\right) / \mathrm{OctCA} 49 / 51$ & 3.7 \\
\hline 4. & $\emptyset(\mathrm{PIB}-\mathrm{CA})_{3}\left(\mathrm{M}_{\mathrm{n}}=2400 \mathrm{~g} / \mathrm{mol}\right) / \mathrm{OctCA} 25 / 75$ & 5.1 \\
\hline 5. & $\emptyset(\mathrm{PIB}-\mathrm{CA})_{3}\left(\mathrm{M}_{\mathrm{n}}=2400 \mathrm{~g} / \mathrm{mol}\right) / \mathrm{OctCA} 49 / 51$ & \\
\hline
\end{tabular}




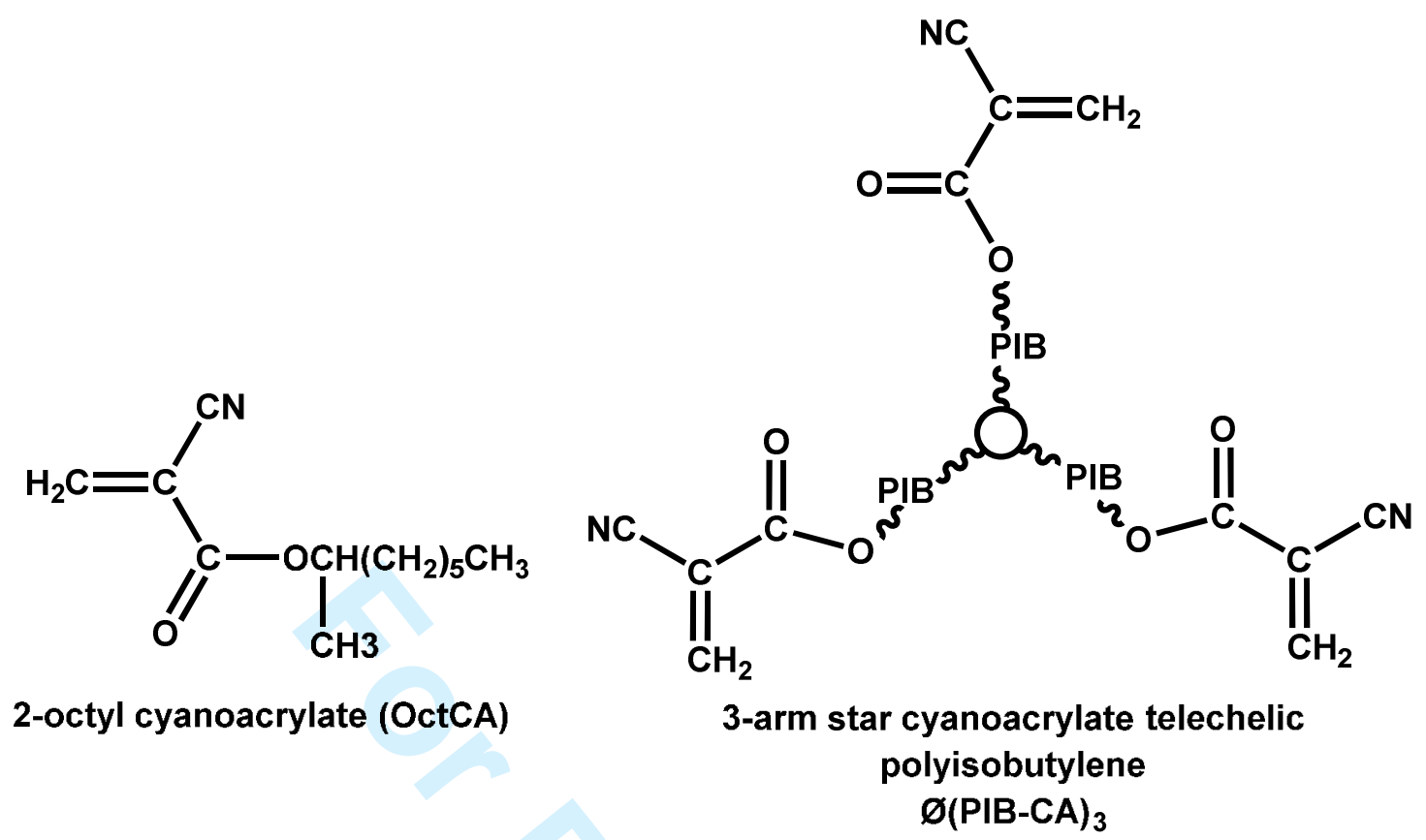

FIGURE 1 Structures of Starting Materials of PIB-based Homo- and Co-networks 


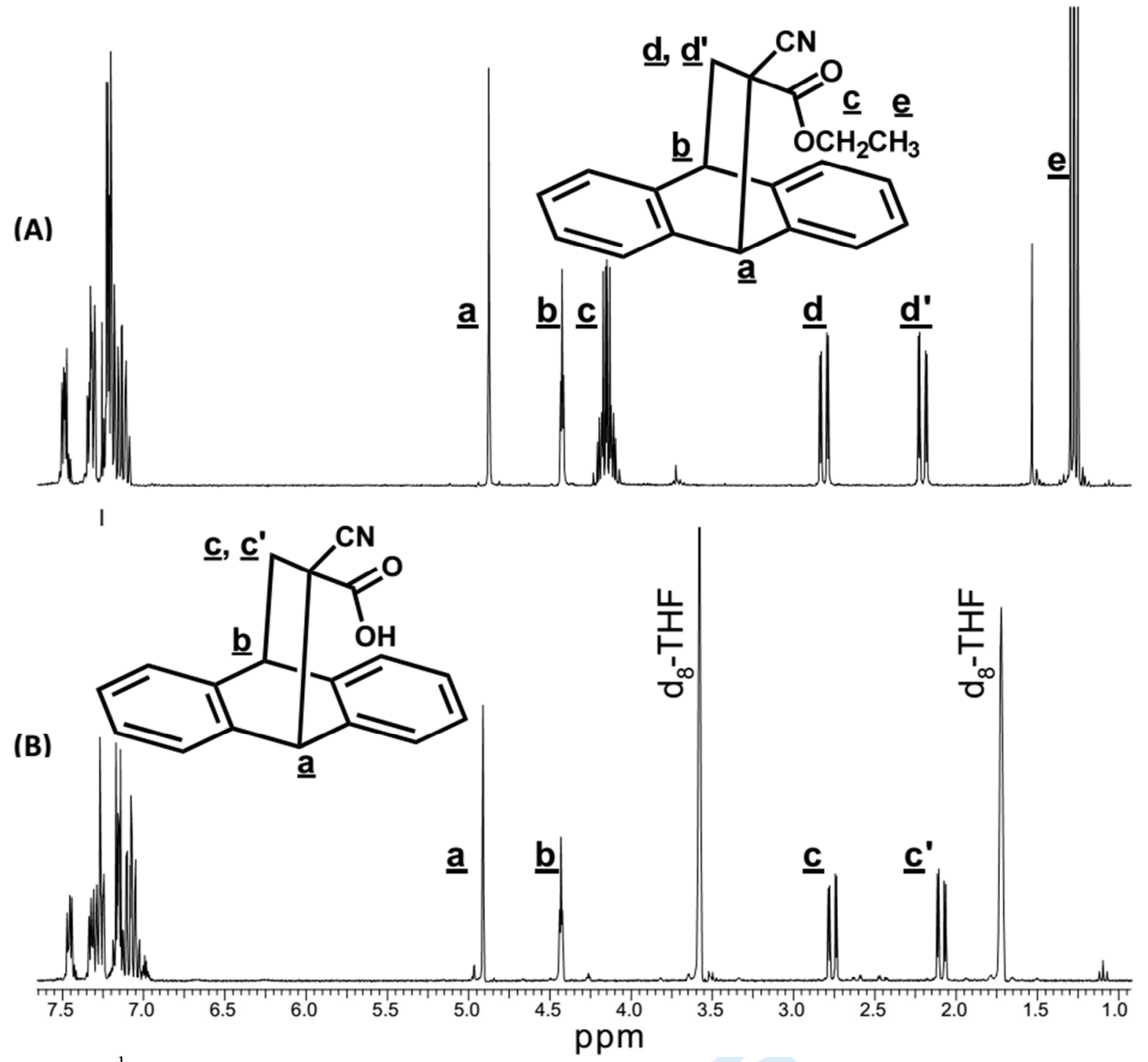

FIGURE $2{ }^{1} \mathrm{H}$ NMR spectra of (A) Ethyl-9,10-dihydro-9,10-endoethanoanthracene-11-cyano11-carboxylate, anthracene-protected 2-cyano acrylic ethyl ester, and (B) 9,10-dihydro-9,10endoethanoanthracene-11-cyano-11-carboxylic acid, anthracene-protected 2-cyanoacrylic acid. 


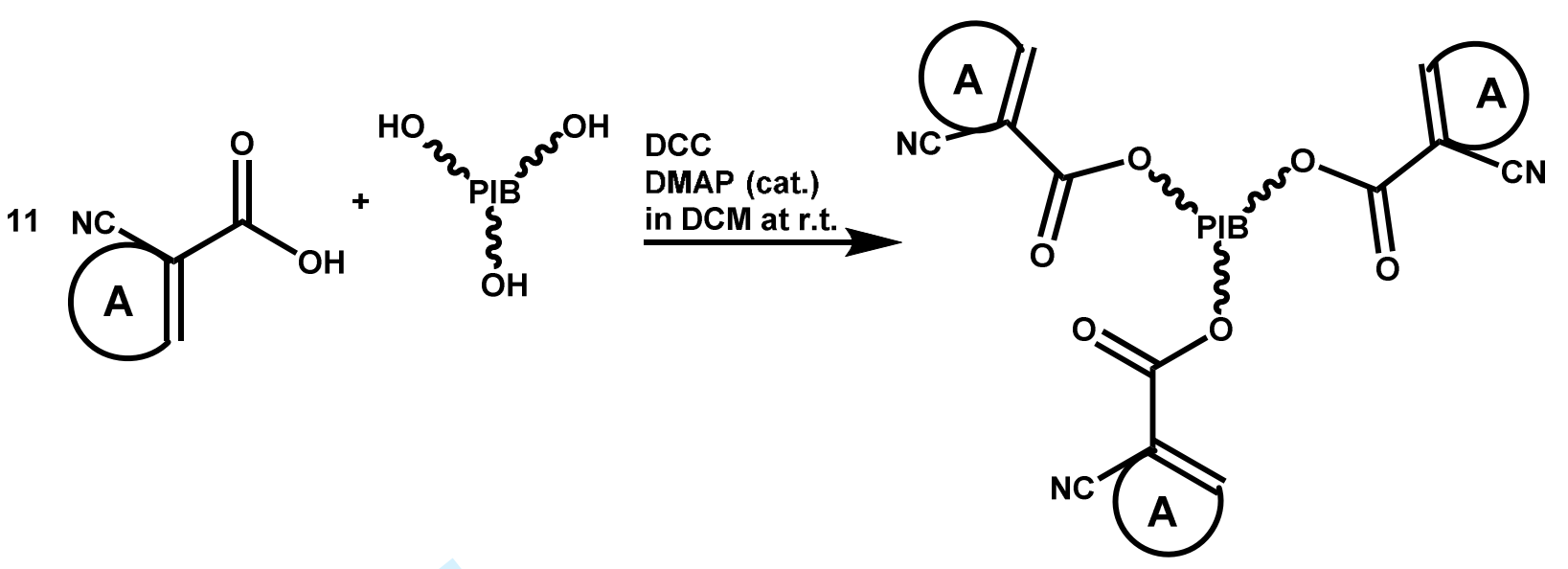



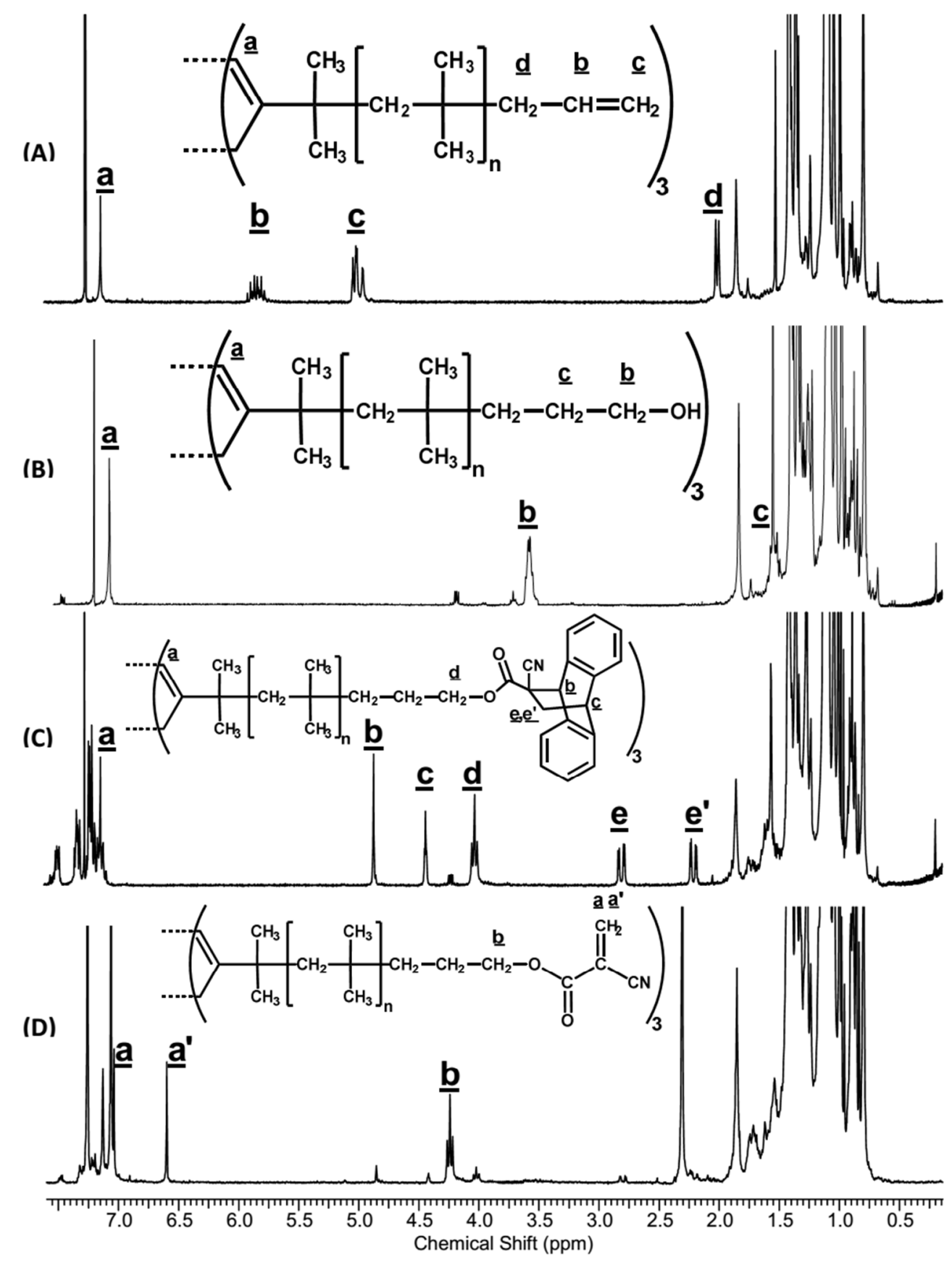

FIGURE $3{ }^{1} \mathrm{H}$ NMR spectra of $\varnothing(\mathrm{PIB}-\mathrm{CA})_{3}$ and intermediates: (A) allyl-, (B) hydroxyl-, (C) anthracene/cyanoacrylate adduct, and (D) cyanoacrylate-tri-telechelic PIB [Ø(PIB$\mathrm{CA})_{3}$. 


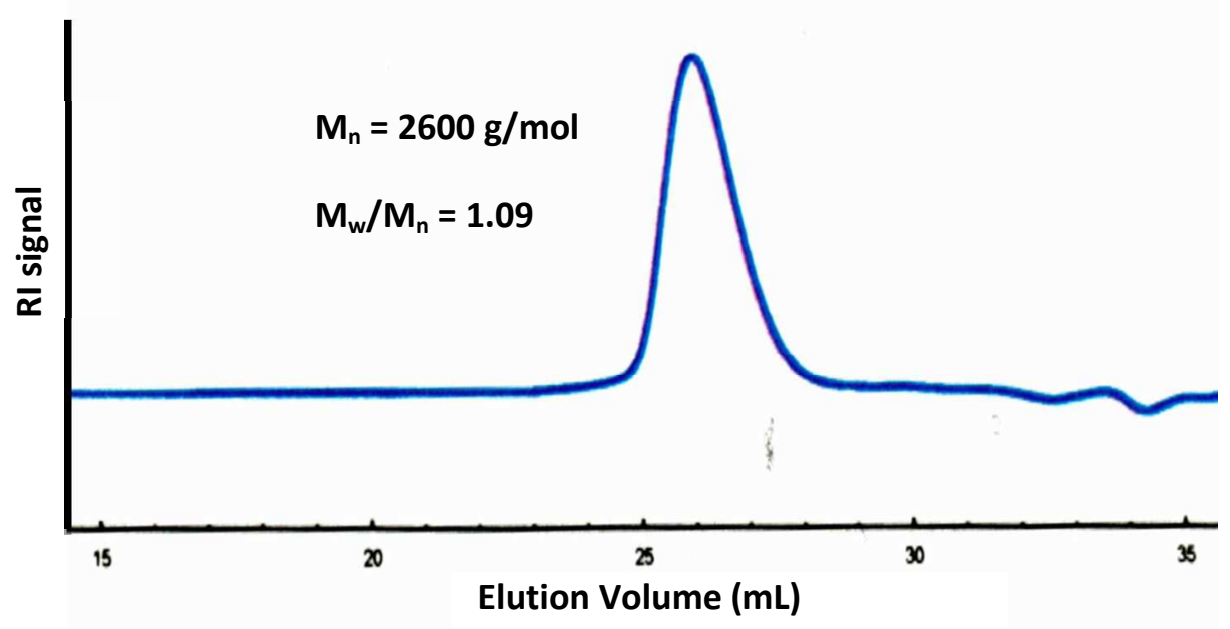

FIGURE 4 GPC trace of a representative three-arm star allyl-tri-telechelic polyisobutylene, the starting material for $\varnothing(\mathrm{PIB}-\mathrm{CA})_{3}$. (See A in Figure 3) 


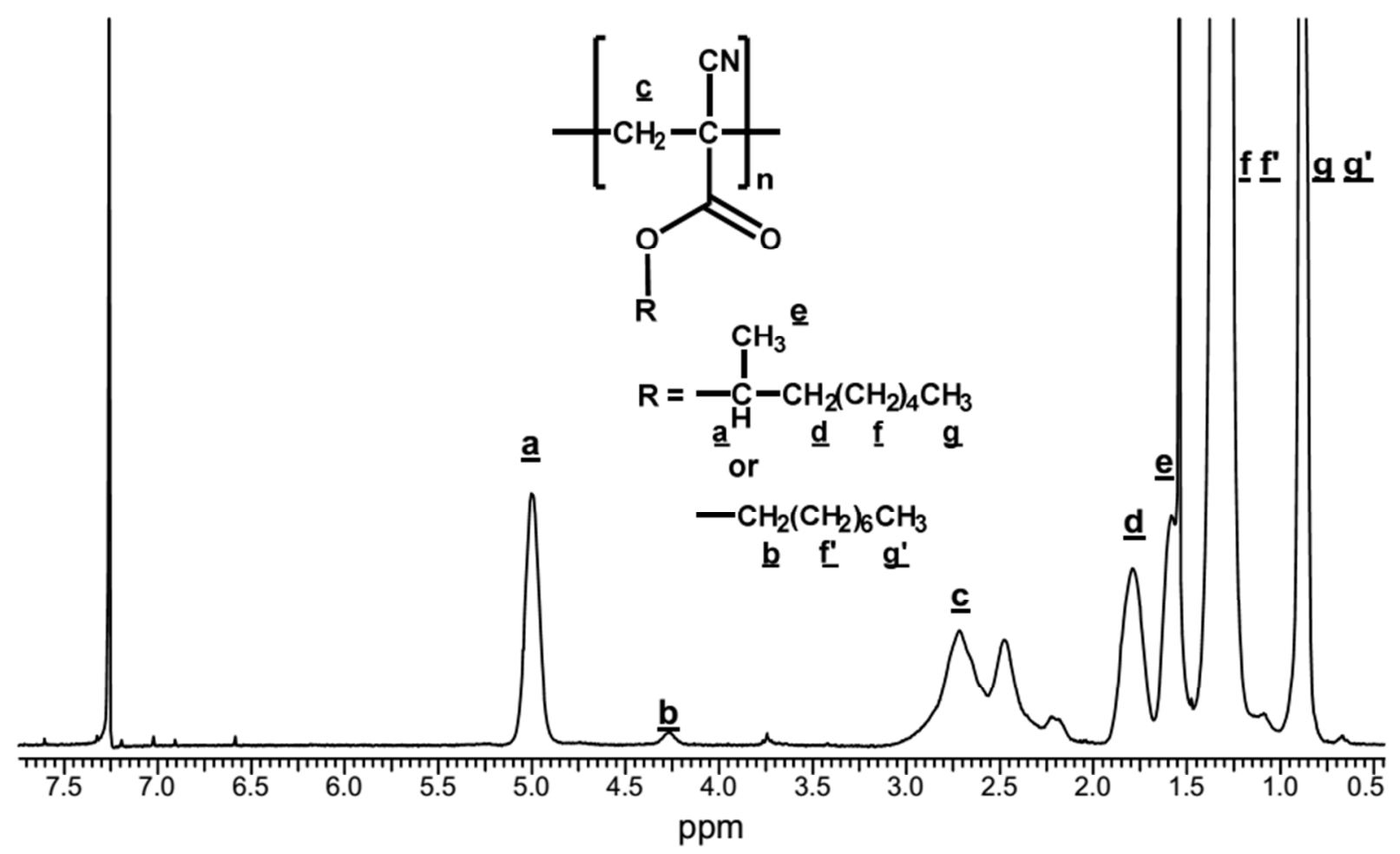

FIGURE $5{ }^{1} \mathrm{H}$ NMR spectrum of poly(2-octyl cyanoacrylate) (the polymer contains $\sim 2 \mathrm{~mol} \%$ of 1-octyl cyanoacrylate) . 


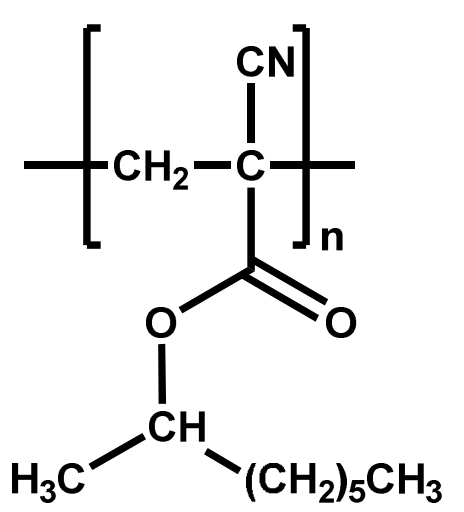

FIGURE 6 The Repeat Structure of Poly(2-octyl cyanoacrylate) 


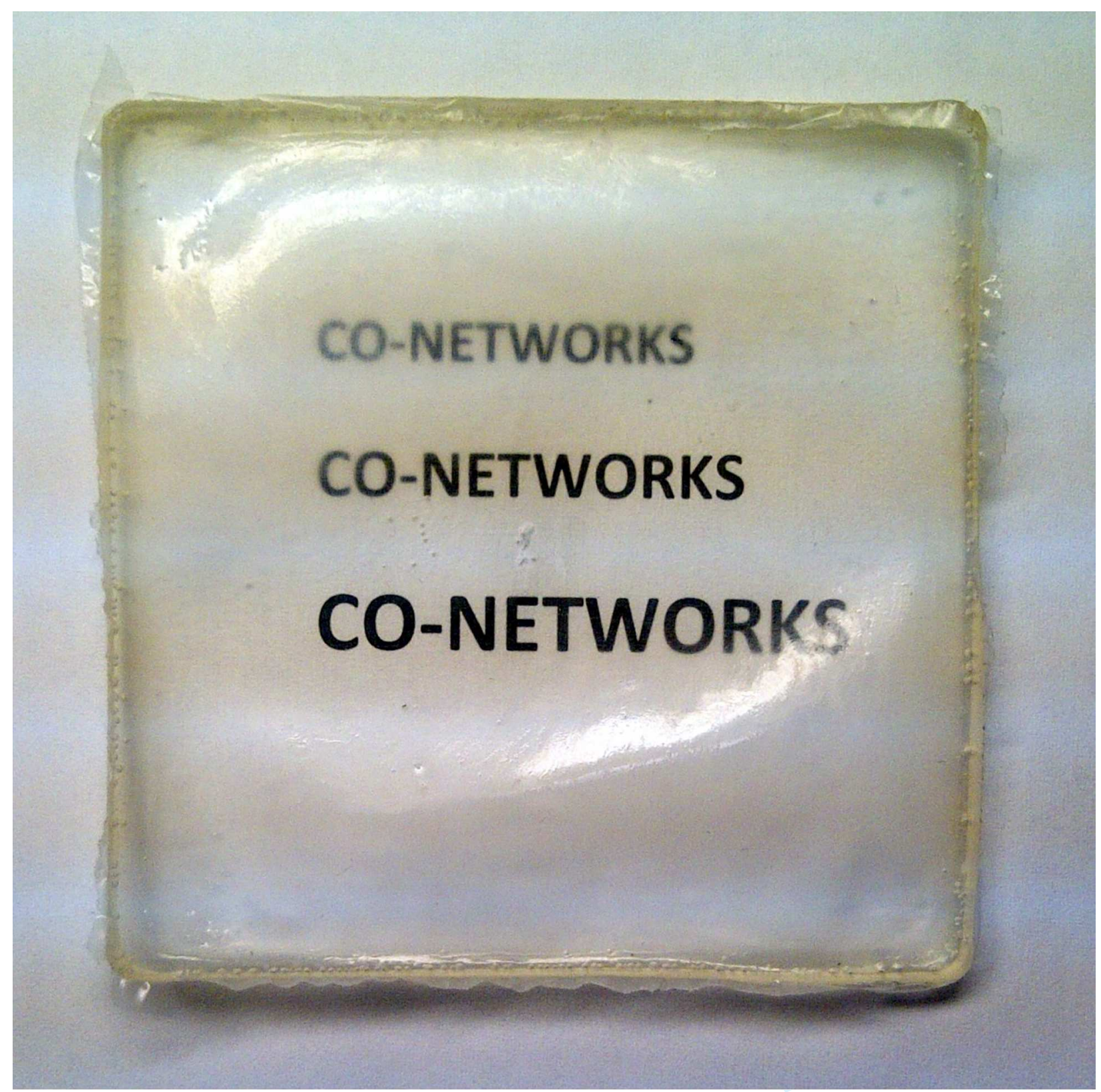

FIGURE 7 Transparency of a Sheet of 25\% Ø(PIB-CA $)_{3}\left(\mathrm{M}_{\mathrm{n}}=2400 \mathrm{~g} / \mathrm{mol}\right)-c o-75 \% \mathrm{P}(\mathrm{OctCA})$ 


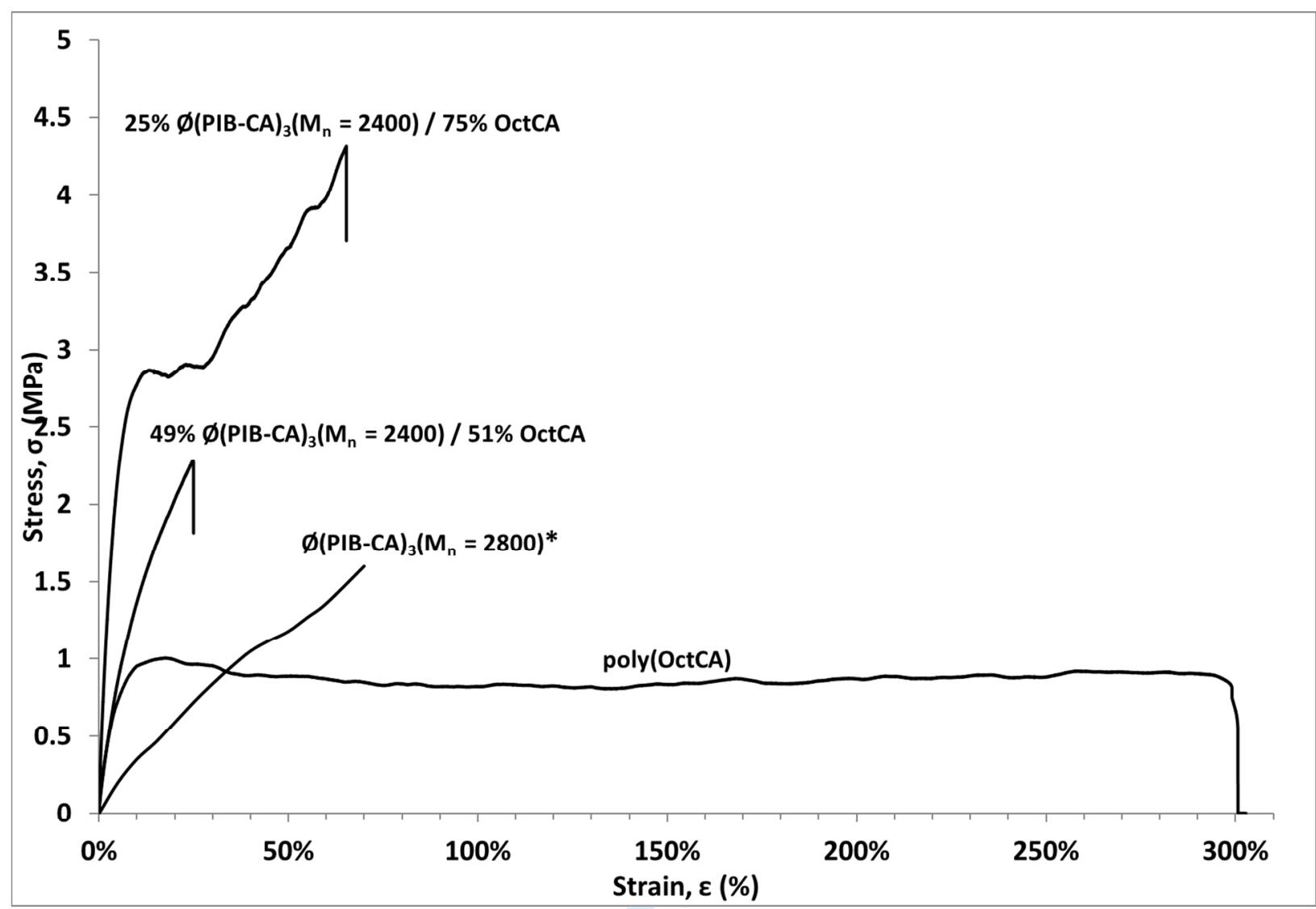

FIGURE 8 Stress-strain traces of a $\mathrm{P}(\mathrm{Oc}-\mathrm{CA})$, a $\varnothing(\mathrm{PIB}-\mathrm{CA})_{3}$ homo-network, and representative $\emptyset(\mathrm{PIB}-\mathrm{CA})_{3}-\mathrm{co}-\mathrm{P}(\mathrm{Oc}-\mathrm{CA})$ co-networks. (Molecular weights and compositions indicated.*From ref. 8) 


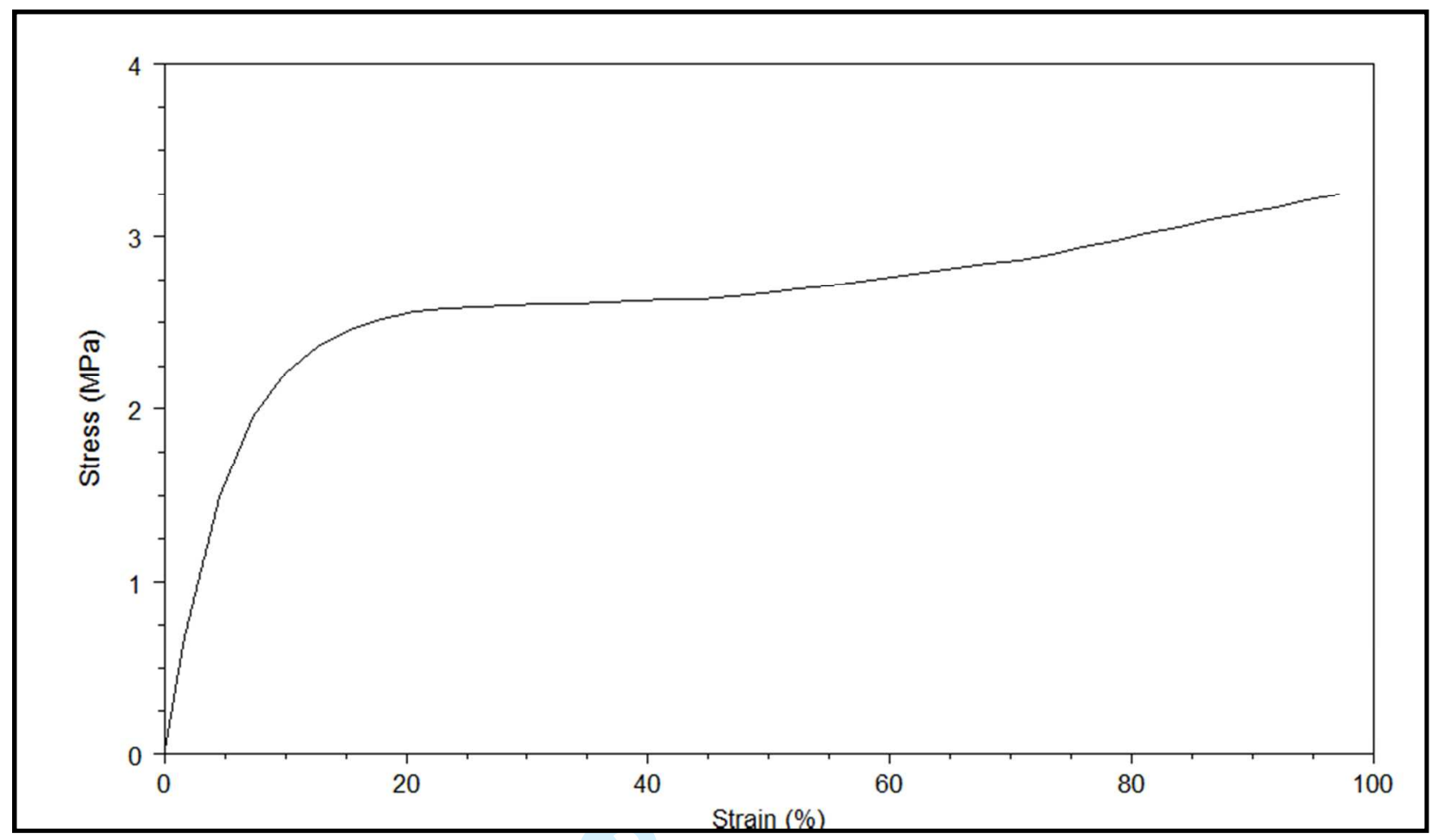

FIGURE 9 Stress-strain trace of a co-network of 25\% Ø(PIB-CA $)_{3}\left(\mathrm{M}_{\mathrm{n}}=2400 \mathrm{~g} / \mathrm{mol}\right)-\mathrm{co}-75 \%$ $\mathrm{P}(\mathrm{OctCA})$, at $30^{\circ} \mathrm{C}$. 


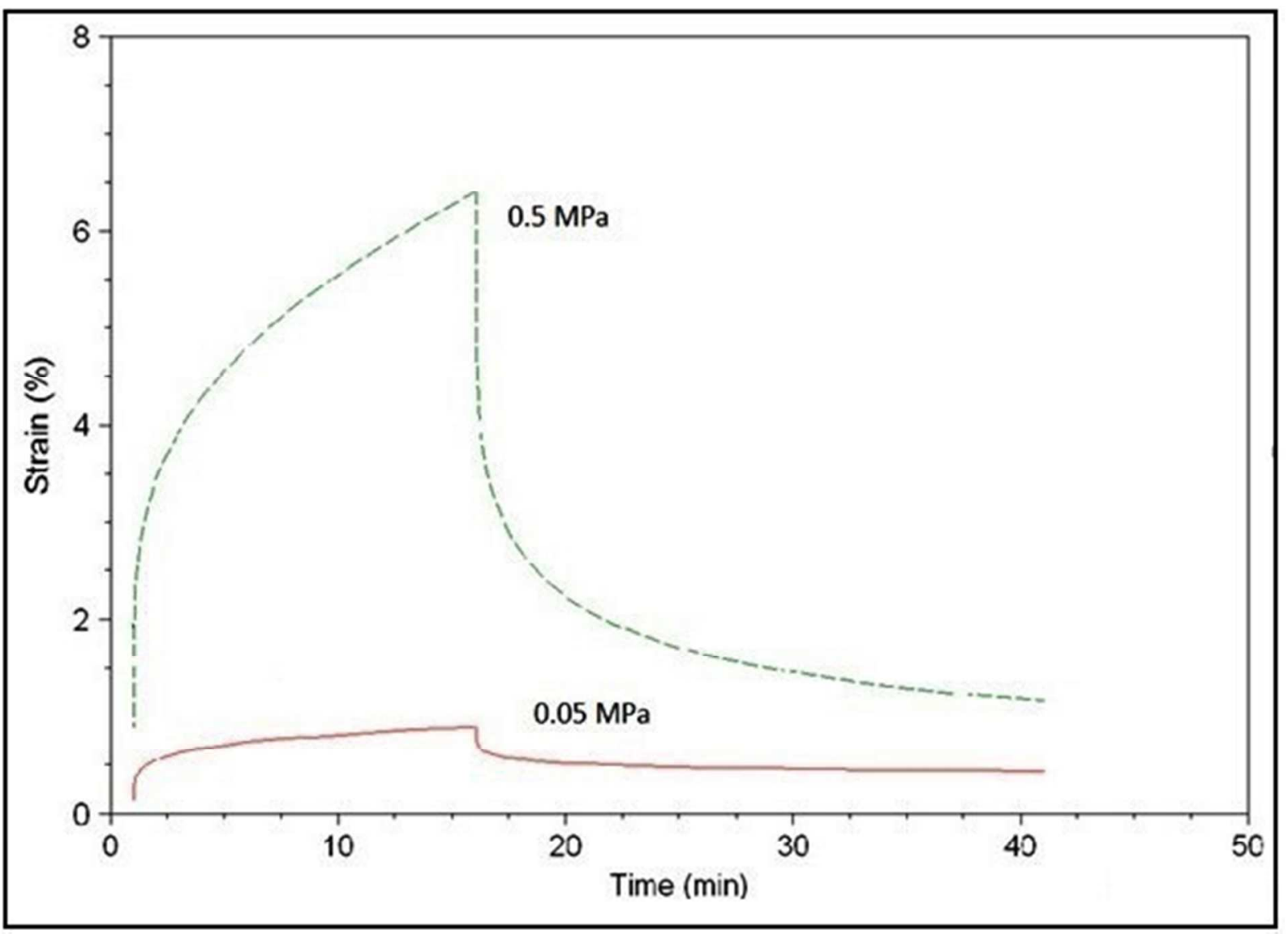

FIGURE 10 Tensile creep strain versus test time for a $25 \% \varnothing(\mathrm{PIB}-\mathrm{CA})_{3}\left(\mathrm{M}_{\mathrm{n}}=2400 \mathrm{~g} / \mathrm{mol}\right)$-co$75 \% \mathrm{P}\left(\right.$ OctCA) co-network, at $30{ }^{\circ} \mathrm{C}$. 


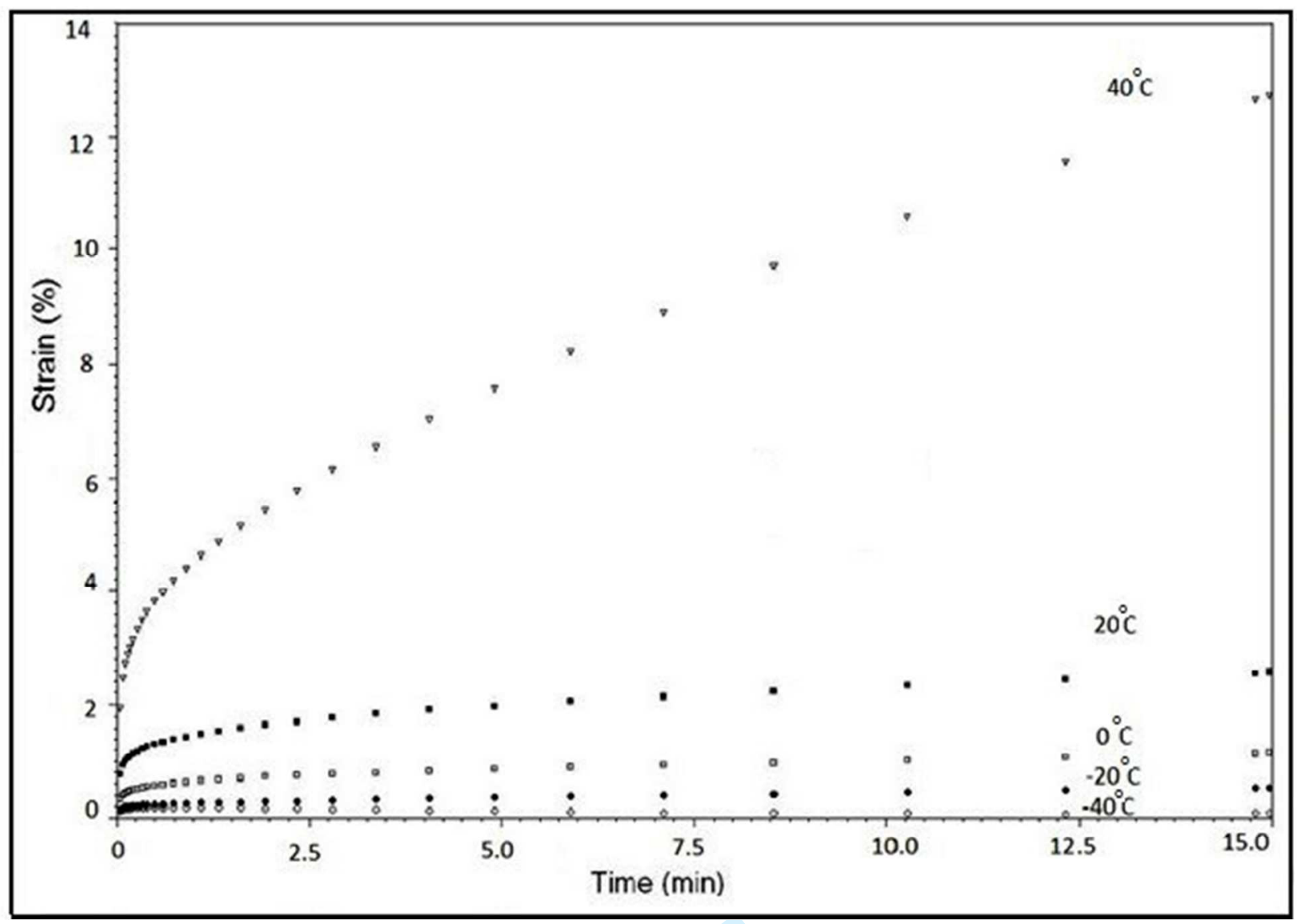

FIGURE 11 Creep curves for a 25\% Ø(PIB-CA $)_{3}\left(\mathrm{M}_{\mathrm{n}}=2400 \mathrm{~g} / \mathrm{mol}\right)-\mathrm{co}-75 \% \mathrm{P}(\mathrm{OctCA})$ conetwork at various temperatures. 


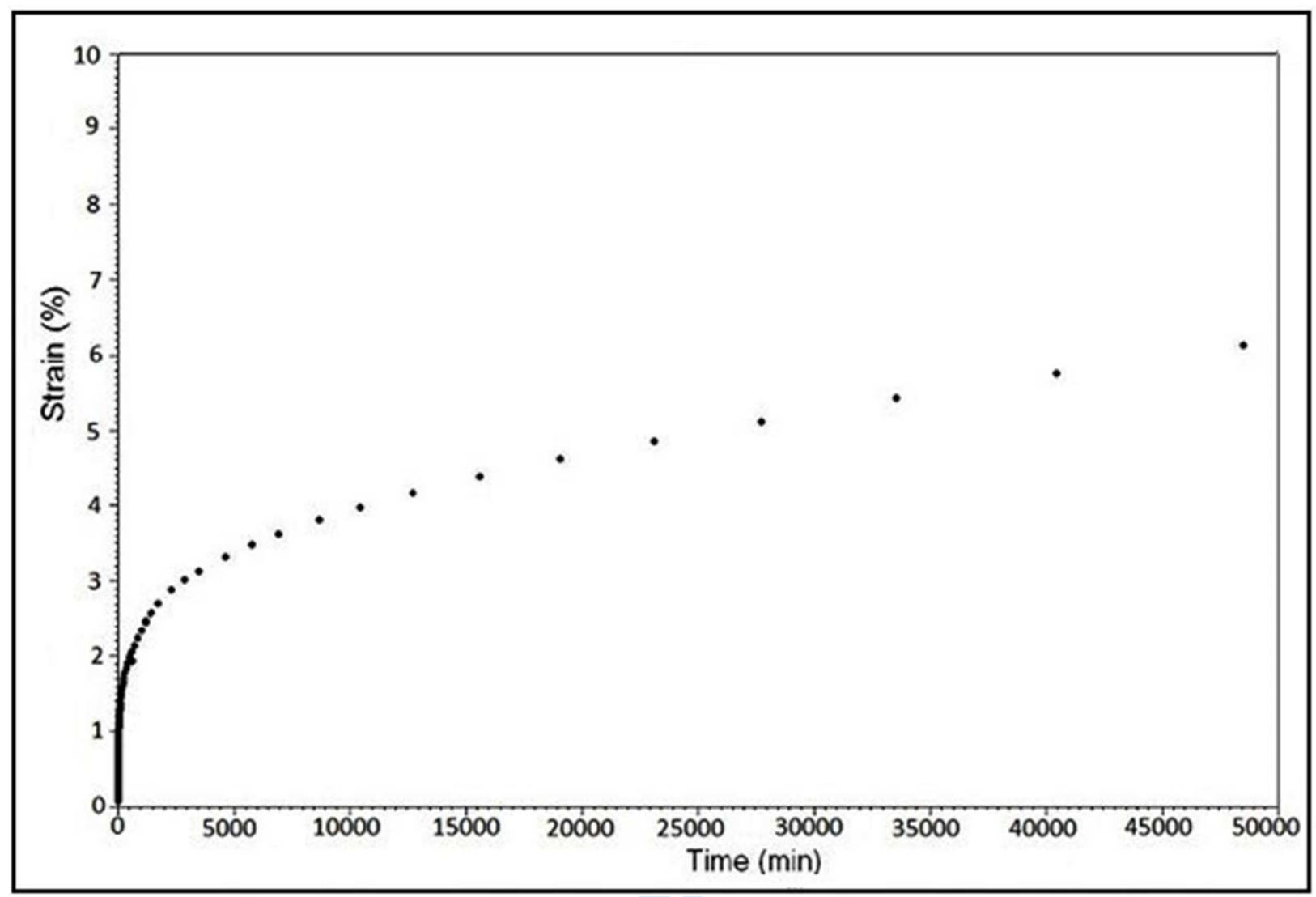

FIGURE 12 TTS master curve for a 25\% $\varnothing(\mathrm{PIB}-\mathrm{CA})_{3}\left(\mathrm{M}_{\mathrm{n}}=2400 \mathrm{~g} / \mathrm{mol}\right)$-co-75\% P(OctCA) conetwork. 


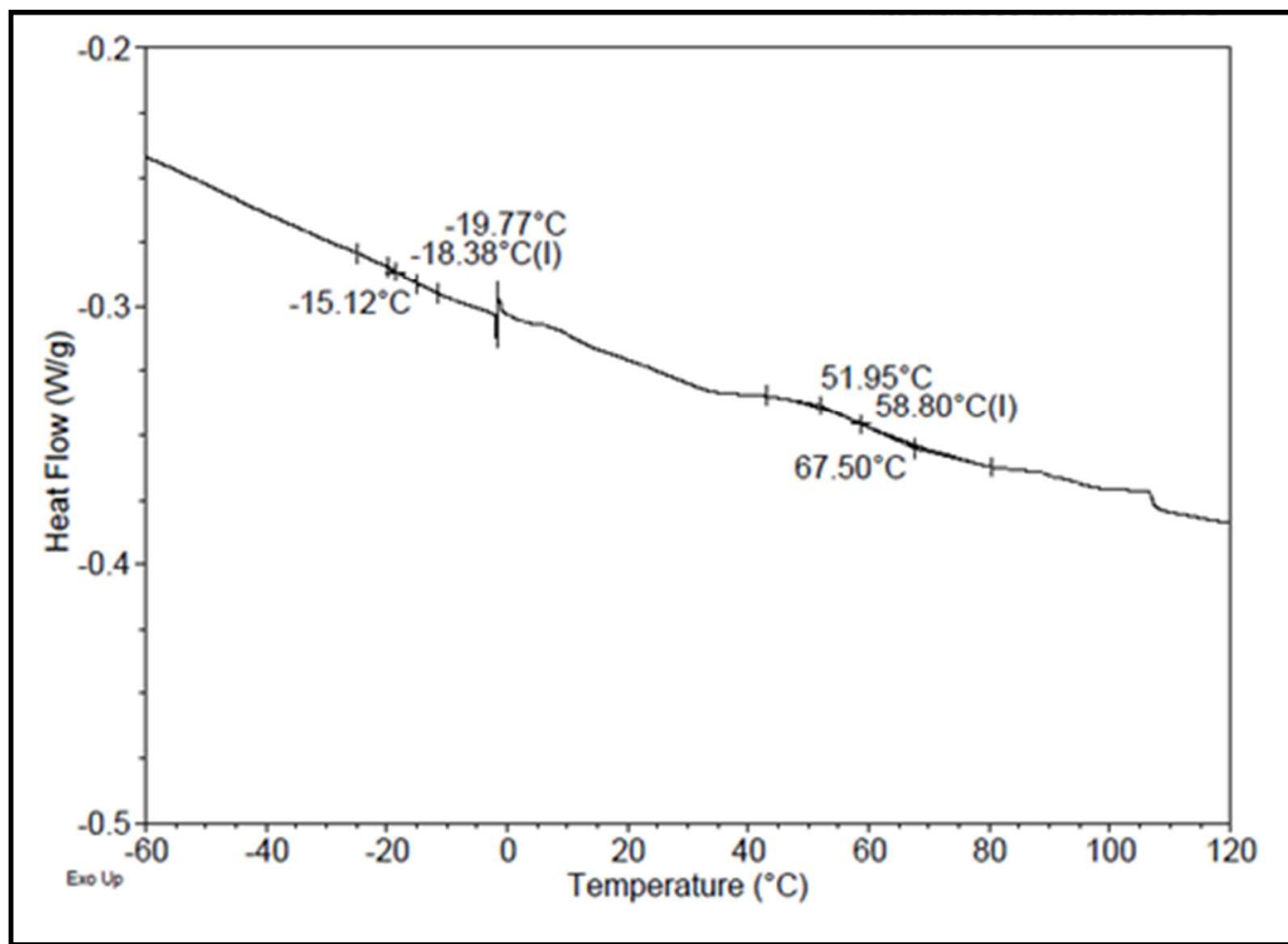

FIGURE 13 DSC trace of 25\% Ø(PIB-CA $)_{3}\left(\mathrm{M}_{\mathrm{n}}=2400 \mathrm{~g} / \mathrm{mol}\right)-\mathrm{co}-75 \% \mathrm{P}($ OctCA $)$ co-network 


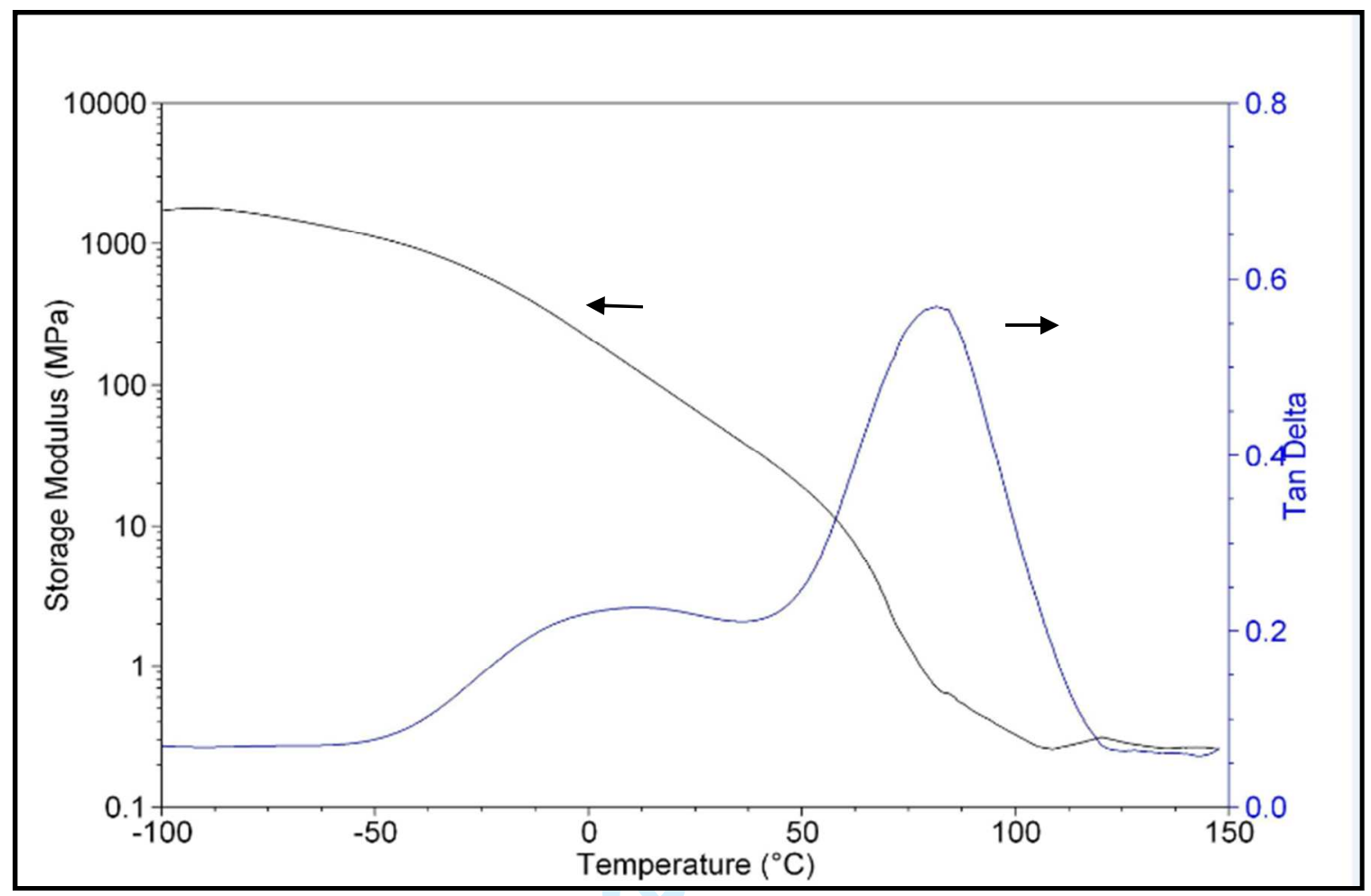

FIGURE 14 DMTA traces of a representative $25 \% \varnothing(\mathrm{PIB}-\mathrm{CA})_{3}\left(\mathrm{M}_{\mathrm{n}}=2400 \mathrm{~g} / \mathrm{mol}\right)-\mathrm{co}-75 \%$ $\mathrm{P}($ OctCA $)$ co-network. 


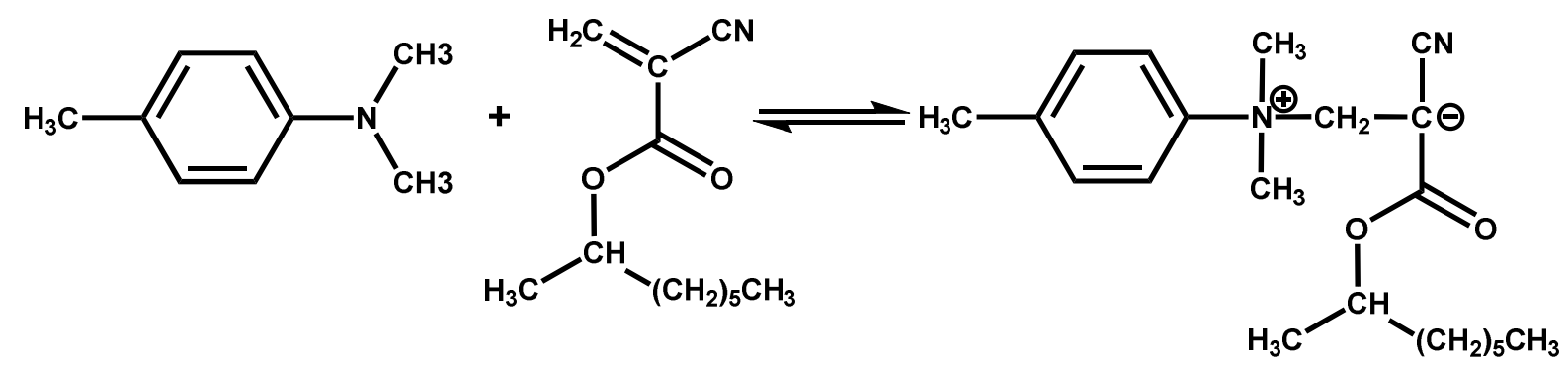




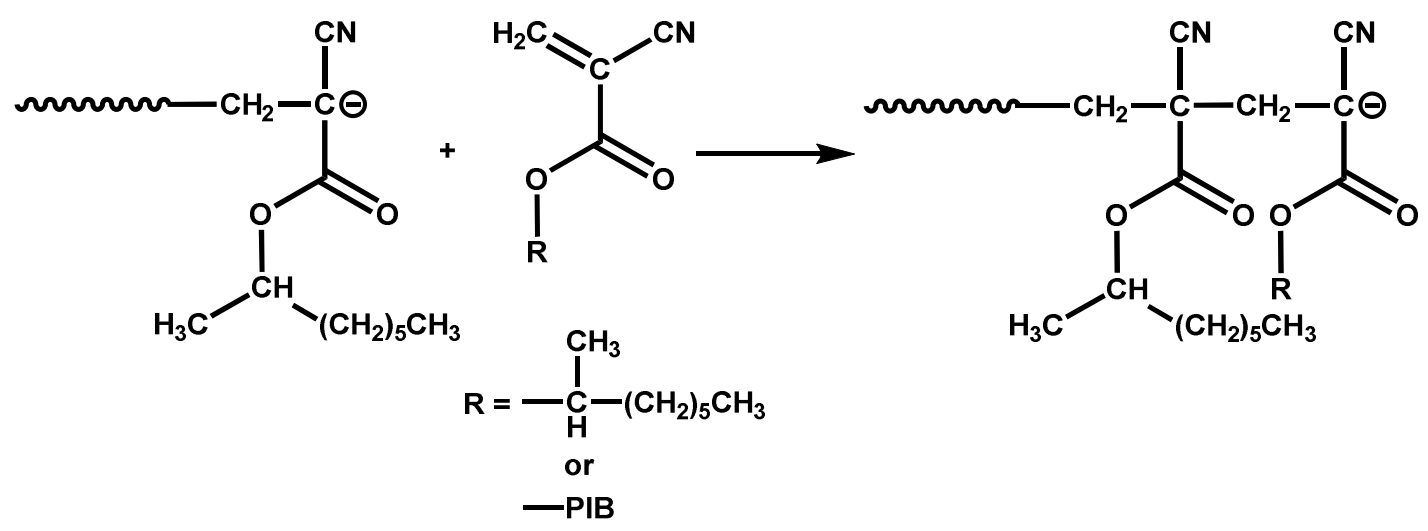




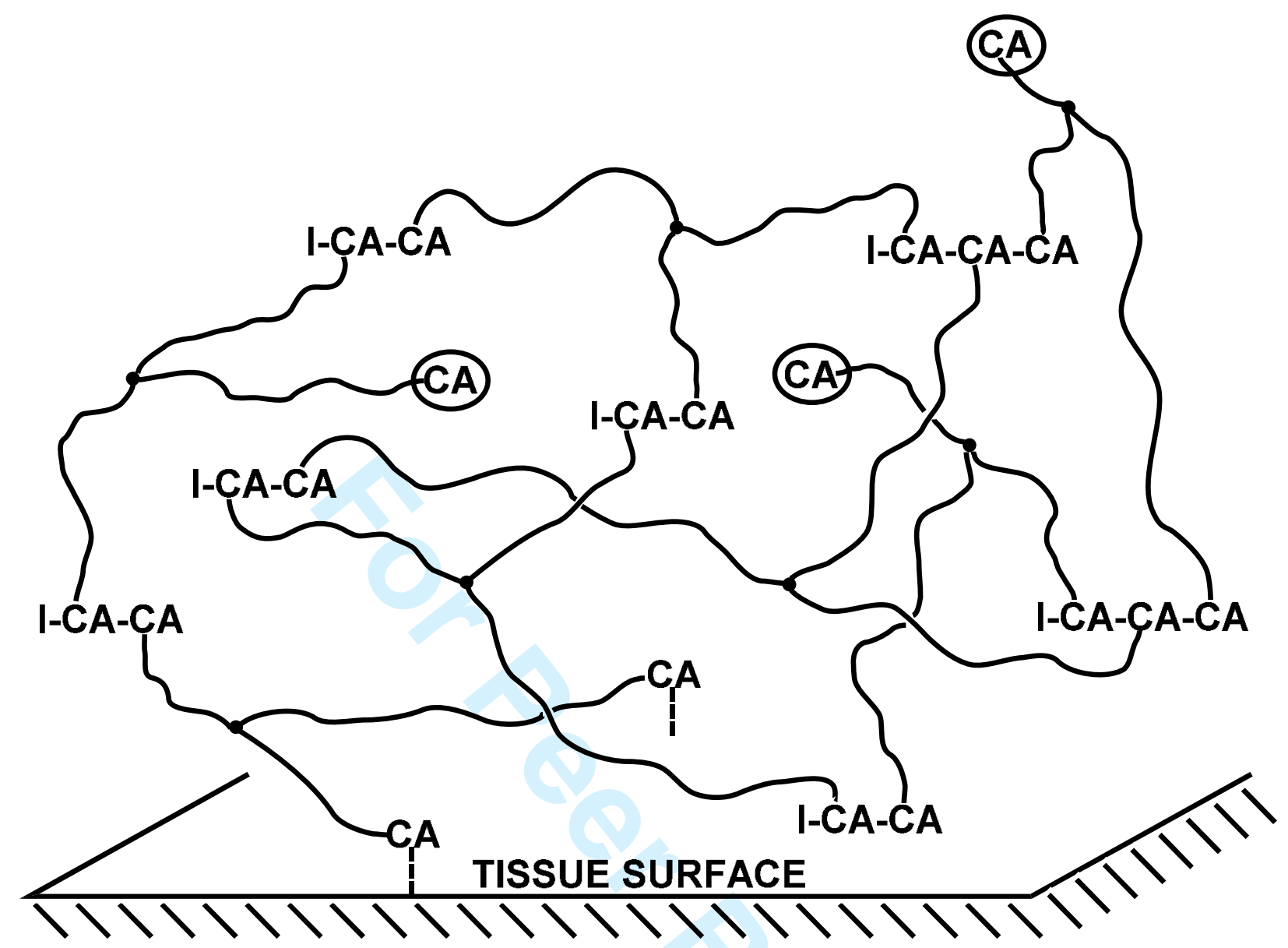

FIGURE 15 Idealized Microstructure of a Rubbery PIB Homo-network Formed of Ø(PIB-CA $)_{3}$ (Wiggly lines $=$ PIB, I $=$ initiator; $\bullet=$ aromatic center of $\varnothing(\mathrm{PIB}-\mathrm{CA})_{3}, \mathrm{CA}---=\mathrm{CA}$ bonded to skin surface, CA in circles = "useless" entrapped CA). Note the loops and entrapped/catenated crosslinks. 


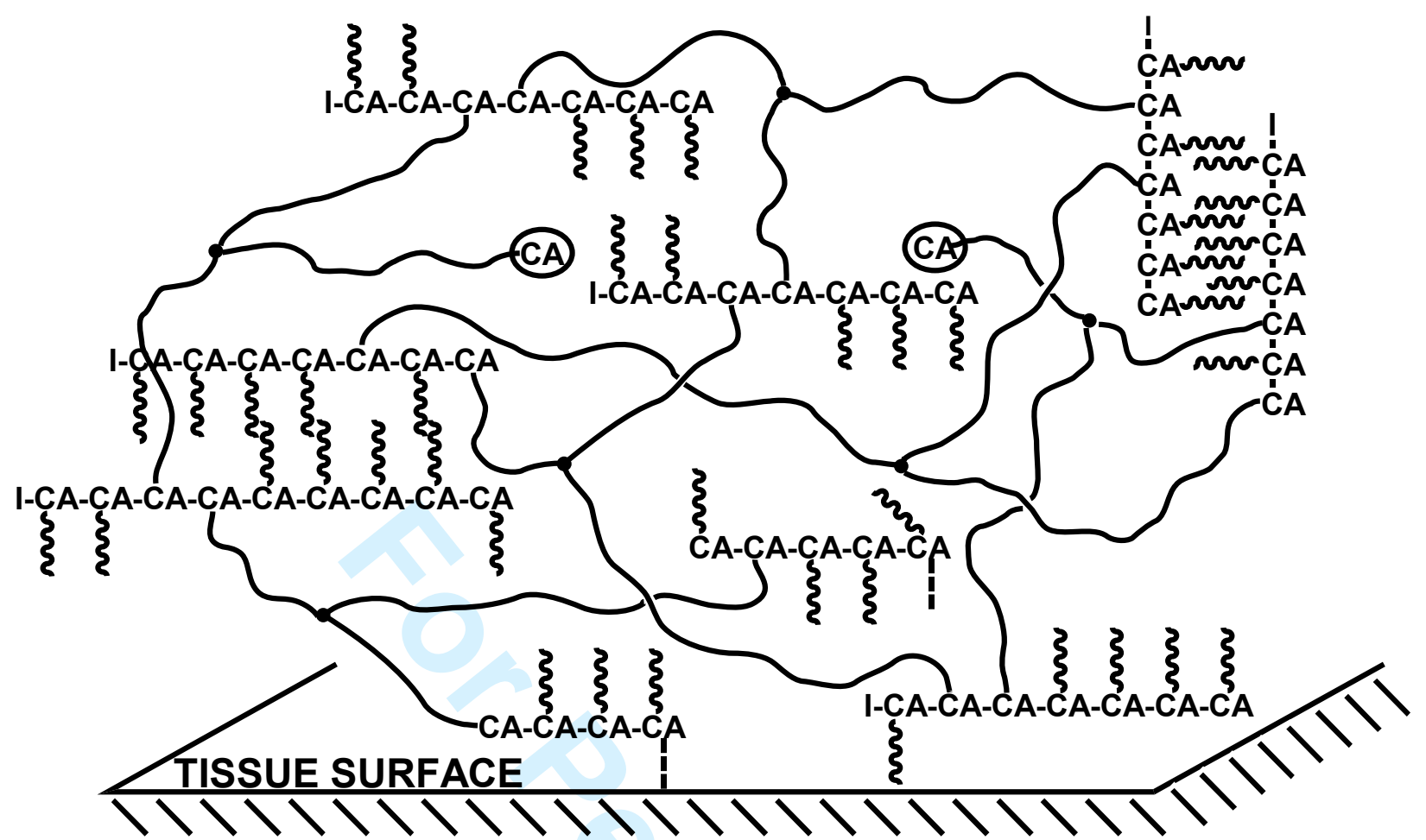

FIGURE 16 Idealized Structure of a 50/50 wt/wt Ø(PIB-CA $)_{3}-c o-P(O c t C A)$ Co-network (Wiggly line =PIB, I=initiator, CA--- = CA bonded to skin surface, CA in circle CA = "useless" CA groups entrapped in matrix, $\bullet=$ aromatic center of $\varnothing(\mathrm{PIB}-\mathrm{CA})_{3}$. Note the presence of catenated/entrapped crosslinks and PIB loops. The polymerization of CA groups is initiated by a purposely added initiator (I), or a nucleophilic group ( $\mathrm{N}$ or $\mathrm{O})$ in the epidermis,(---), or by traces of moisture. 